OPEN ACCESS

Edited by:

Gerhard Josef Herndl, University of Vienna, Austria

Reviewed by: Alexander B. Bochdansky, Old Dominion University, United States

Travis Blake Meador, Academy of Sciences of the Czech Republic (ASCR), Czechia

*Correspondence: Aristomenis Karageorgis ak@hcmr.gr

Specialty section: This article was submitted to Biogeoscience, a section of the journal Frontiers in Earth Science

Received: 06 October 2020 Accepted: 30 July 2021 Published: 16 August 2021

Citation:

Chaikalis S, Parinos C, Möbius J, Gogou A, Velaoras D, Hainbucher D,

Sofianos S, Tanhua T, Cardin V, Proestakis E, Amiridis V, Androni A and Karageorgis A (2021) Optical Properties and Biochemical Indices of Marine Particles in the Open Mediterranean Sea: The R/N Maria S.

Merian Cruise, March 2018.

Front. Earth Sci. 9:614703. doi: 10.3389/feart.2021.614703

\section{Optical Properties and Biochemical Indices of Marine Particles in the Open Mediterranean Sea: The $R / V$ Maria S. Merian Cruise, March 2018}

\author{
Spyros Chaikalis ${ }^{1,2}$, Constantine Parinos ${ }^{1}$, Jürgen Möbius ${ }^{3}$, Alexandra Gogou ${ }^{1}$, \\ Dimitris Velaoras ${ }^{1}$, Dagmar Hainbucher ${ }^{4}$, Sarantis Sofianos ${ }^{2}$, Toste Tanhua ${ }^{5}$, \\ Vanessa Cardin ${ }^{6}$, Emmanouil Proestakis ${ }^{7}$, Vassilis Amiridis ${ }^{7}$, Afrodite Androni ${ }^{1}$ and \\ Aristomenis Karageorgis ${ }^{1 *}$
}

${ }^{1}$ Institute of Oceanography, Hellenic Centre for Marine Research (HCMR), Anavyssos, Greece, ${ }^{2}$ Ocean Physics and Modelling Group, National and Kapodistrian University of Athens, Athens, Greece, ${ }^{3}$ Institute for Coastal Research, Helmholtz-Zentrum Geesthacht, Geesthacht, Germany, ${ }^{4}$ Institut für Meereskunde, CEN, Universität Hamburg, Hamburg, Germany, ${ }^{5}$ GEOMAR Helmholtz Centre for Ocean Research Kiel, Kiel, Germany, ${ }^{6}$ Istituto Nazionale di Oceanografia e di Geofisica Sperimentale - OGS, Sgonico, Italy, ${ }^{7}$ Institute for Astronomy, Astrophysics, Space Applications and Remote Sensing, National Observatory of Athens, Athens, Greece

A rich data set on particulate matter optical properties and parameters (beam attenuation coefficient, volume concentration, particle size and PSD slope), accompanied by measurements of biochemical indices (particulate organic carbon, particulate nitrogen and their stable isotopic composition) was obtained from the surface to deep waters across the Mediterranean Sea, in March-April 2018. A decrease of beam attenuation coefficients, total particle volume concentrations, particulate organic carbon and nitrogen concentrations was noted towards the eastern Mediterranean Sea (EMed) in comparison to the western Mediterranean Sea (WMed). LISST-derived optical properties were significantly correlated with water mass characteristics. Overall, the most turbid water mass identified in the Mediterranean Sea was the Surface Atlantic water (AW), and the most transparent was the Transitional Mediterranean Water (TMW) in the Cretan Sea, whereas a general decrease in particulate matter concentration is observed from the WMed towards the EMed. Relatively depleted $\delta^{13} \mathrm{C}$-POC values in the particle pool of the open Mediterranean Sea can be attributed to contribution from terrestrial inputs, mainly via atmospheric deposition. Throughout the entire water column, a significant positive correlation between particle beam attenuation coefficient and particulate organic carbon concentration is observed in the open Mediterranean Sea. Such relationship suggests the predominance of organic particles with biogenic origin. POC concentration and particle median diameter $\mathrm{D}_{50}$ are significantly and negatively correlated both in the WMed and the EMed Sea, confirming that small particles are POC-rich. At depth, a prominent decrease of most measured parameters was observed, with the exception of particle median diameter that increased substantially in the EMed towards the deep sea, suggesting potentially enhanced aggregation processes. The low particle size distribution slope $\xi$ observed in the EMed, corresponding to larger particle populations, supports the above notion. Basin-wide Rayleigh-type isotopic fractionation in vertical profiles of 
$\delta^{15} \mathrm{~N}-\mathrm{PN}$ across the Mediterranean Sea, underlines the differences in the trophic characters of the two sub-basins and highlights the role of circulation changes on biogeochemical parameters and the redistribution of particulate matter as a source of nutrients in the water column.

Keywords: particle dynamics, optical oceanography, LISST-Deep, PSD slope, POC, PN, $\delta^{13} \mathrm{C}-\mathrm{POC}, \delta^{15} \mathrm{~N}-\mathrm{PN}$

\section{INTRODUCTION}

The vertical distribution, horizontal distribution, and export at depth of particulate matter (PM) in the world ocean have been the subject of numerous studies over the past decades (Volk and Hoffert, 1985; Honjo et al., 2008; Jeandel et al., 2015). PM is mostly generated in the ocean's surface layers through primary production and the small fraction that survives remineralization in the upper ocean is exported through physical mixing, aggregation and disaggregation, repackaging and gravitational sinking downwards to the deep sea. During its transit towards the seafloor, most of the particulate organic carbon (POC) particulate nitrogen $(\mathrm{PN})$ and particulate organic phosphorus (POP) is returned to their inorganic forms and redistributed into the water column. This redistribution determines the surface concentration of dissolved $\mathrm{CO}_{2}$ and inorganic nutrients and hence the rate at which the ocean can absorb $\mathrm{CO}_{2}$ from the atmosphere. The ability to quantitatively predict the depth profile of POC remineralization is therefore critical for evaluating the response of the ocean carbon cycle to global change. Processes involved in particle formation, remineralization and transport from the epipelagic to the mesopelagic and bathypelagic ocean are tightly connected to the biochemistry of marine organisms and the biodiversity and health of marine ecosystems.

Optical methods have been used for decades to describe PM behavior in the marine environment, as particle quality, distribution, abundance and size, directly affect light scattering in the ocean, and subsequently regulate the oceans' optical properties and the water-leaving radiance measured remotely from satellites (Twardowski et al., 2001; Buonassissi and Dierssen, 2010; Karageorgis et al., 2012; Kostadinov et al., 2012; Xi et al., 2014). In particular, particle size distribution quantifies the concentration of particles as a function of particle size, playing a critical role in the determinations of the light scattering and absorption properties of seawater, and thus the penetration of light within the ocean (Runyan et al., 2020). Despite its utility, little is known about the natural variability of the particle size distribution (PSD) due to challenges inherent with its measurement (Buonassissi and Dierssen, 2010). This holds particularly true in the case of deep regional seas, such as the oligotrophic ocean, where very limited particle size data are available to the oceanographic community, mainly due to instrumental limitations, since instruments measuring in-situ particle size at deep waters are so few.

Optical studies in the oligotrophic, open Mediterranean Sea have been limited over past decades, yet can be traced back to the 1990s with the pioneering work of Bricaud et al. $(1995,1998)$ and Loisel and Morel (1998), and more recently by Loisel et al. (2011), Moutin et al. (2012). Utilizing beam transmissometers, optical instruments routinely used to measure the concentration of suspended particulate matter, and describe the temporal and spatial variability of PM in marine waters, Karageorgis et al. (2008) synthesized numerous transmissometer profiles in the eastern Mediterranean Sea, whereas Karageorgis et al. (2012) reported the PM optical and size properties in the Ionian Sea.

Concerning the quality and origin of the marine PM, valuable information can be obtained by the stable isotopic composition of significant elements such as carbon and nitrogen, which constitutes a tracer of surface biological and biochemical processes, thus providing deeper insight into the physical and biogeochemical processes during its transport towards the deep ocean (Wu et al., 1999). The use of stable isotopes as a mean for source identification is based on the concept that carbon and nitrogen are interrelated in many forms, and measurable differences in the isotopic composition of the source-materials will persist through their biogeochemical cycling (Stumm and Morgan, 1981; Peterson and Fry, 1987). Moreover, transformation processes cause isotopic fractionation between substrates and products (Kerhervé et al., 2001).

As the ${ }^{15} \mathrm{~N}$ atom is heavier than the ${ }^{14} \mathrm{~N}$ atom, molecules containing ${ }^{15} \mathrm{~N}$ are usually less reactive than those containing ${ }^{14} \mathrm{~N}$, leading to a slight discrimination against ${ }^{15} \mathrm{~N}$ in almost every noequilibrium transformation in the N-cycle (Wada and Hattori, 1991; Altabet, 1996; Waser et al., 1998; Möbius, 2013). According to the ${ }^{14} \mathrm{~N}$ preference, residual substrate of any reaction (i.e. $\mathrm{NO}_{3}$ ) becomes enriched in ${ }^{15} \mathrm{~N}$, whereas the product (i.e. assimilated $\mathrm{N}$ ) is depleted in ${ }^{15} \mathrm{~N}$ compared to the substrate. For this "Rayleigh" type fractionation, the intensity, the so-called fractionation factor ${ }^{15} \varepsilon(\%)$, is defined either as the difference in $\delta^{15} \mathrm{~N}$ between product and substrate or as the slope of the logarithmic function $\delta^{15} \mathrm{~N} v s$ the concentration of product or substrate (Mariotti et al., 1981) if additional sources or sinks are negligible. Because of the aforementioned processes, each $\mathrm{N}$-pool has a specific isotopic signature, resulting from the balance of source and sink terms and their isotopic fractionation. Accordingly, the $\delta^{15} \mathrm{~N}$ of marine particulate matter reflects the interplay of isotopically distinct $\mathrm{N}$ sources as well as the isotopic fractionation processes during both its formation (as a product of assimilation) and its decomposition (as the substrate of ammonification).

The study of the natural isotopic variations of organic carbon $\left(\delta^{13} \mathrm{C}_{\mathrm{org}}\right)$ presents another important method used to trace sources and transformation processes of the particulate organic matter in the marine environment. The isotopic variations of carbon in the organic particles initially present depletion in ${ }^{13} \mathrm{C}$, which derives from the formation procedures of the organic matter during primary production (Kerhervé et al., 2001). Then, as in the case of nitrogen, a stepwise enrichment of

${ }^{13} \mathrm{C}$ occurs in the particles through the food chain and by the 


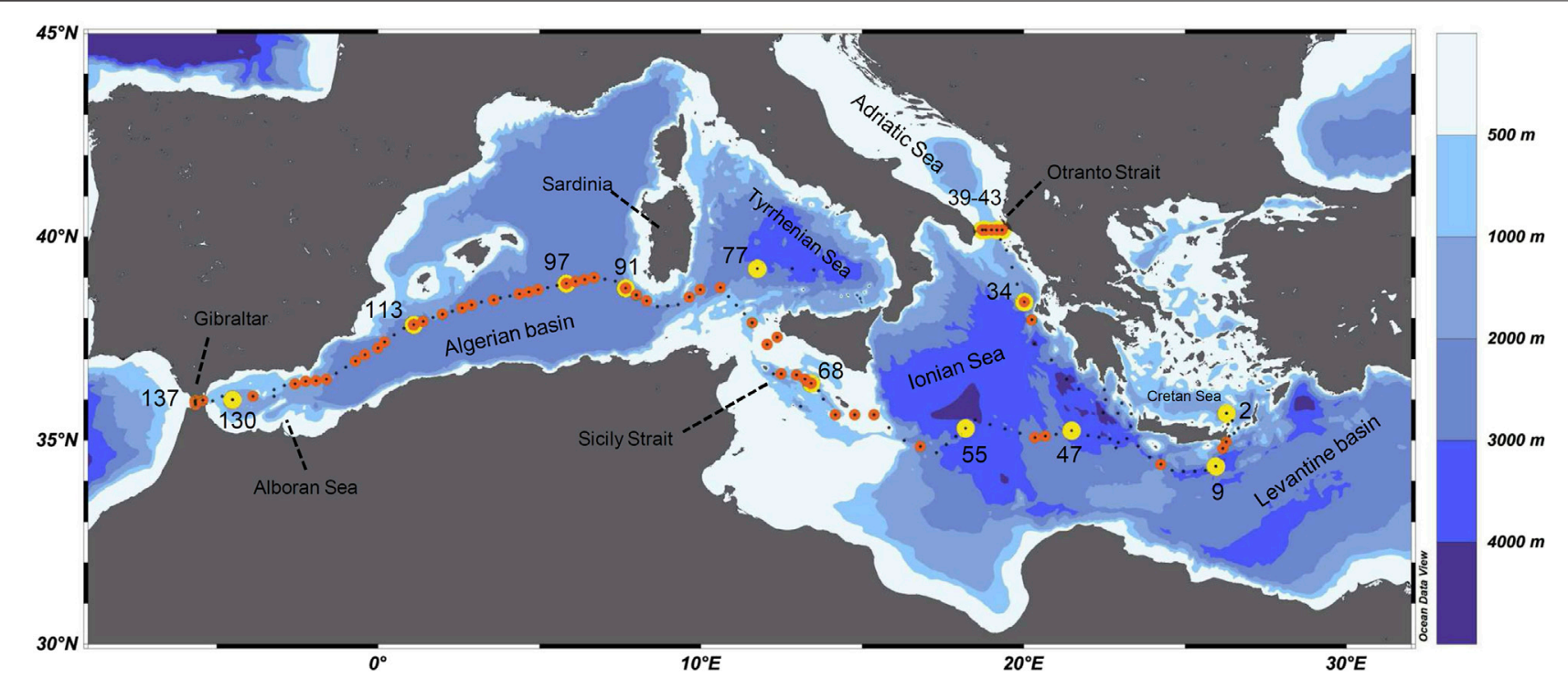

FIGURE 1 | The study area map annotated with major features discussed in the text. Black dots correspond to CTD casts; orange circles correspond to stations where optical parameters of particulate matter were obtained by using the LISST-Deep; while yellow circles correspond to stations where seawater samples were collected for the elemental and stable isotopic analysis of carbon and nitrogen of particulate matter.

processes that are performed at the successive trophic levels (Altabet, 1996). Accordingly to this, the isotopic ratios of carbon, are affected both by the biological sources of the particles and the transformation processes that they undergo during their transfer (Kerhervé et al., 2001).

The oligotrophic seas are ideal settings for studying isotopic composition patterns because sources of nitrogen and carbon vary spatially and temporally, and each with a distinct isotopic composition (Meador et al., 2007). So far, the studies that have been performed on $\delta^{13} \mathrm{C}$-POC and $\delta^{15} \mathrm{~N}-\mathrm{PN}$ in the Mediterranean Sea were focused mainly on sinking organic matter (Kerhervé et al., 2001; Çoban-Yildiz et al., 2006; Emeis et al., 2010; Möbius et al., 2010; Pedrosa-Pàmies et al., 2016). To the best of our knowledge, there are only a few studies reporting on the isotopic composition of $\mathrm{PN}$ in suspended particles in the Mediterranean Sea (Struck et al., 2001; Pantoja et al., 2002; Çoban-Yildiz et al., 2006; Koppelmann et al., 2009; Emeis et al., 2010; Pavlidou et al., 2020) and none that provide the isotopic composition of POC in suspended particles along the entire water column, from the surface to deep waters, across the open Mediterranean Sea.

In this study, optical (transmissometry and particle-size spectra) and biochemical (POC, PN concentrations, and their stable isotopic composition $\delta^{13} \mathrm{C}$-POC and $\delta^{15} \mathrm{~N}-\mathrm{PN}$ respectively) data of marine PM were collected during the MSM72 transMediterranean Sea oceanographic cruise onboard the German $R$ / $V$ Maria S. Merian in spring 2018. The cruise was designed to contribute towards the understanding of interannual changes and trends in the physical and biogeochemical status of the oligotrophic Mediterranean Sea and to further record the hydrological status following the climatological shifts that were observed in the eastern and western part of the basin during the last decades (Durrieu De Madron et al., 2011; Cardin et al., 2015).
An east-to-west transect across the EMed and the WMed was conducted, and multidisciplinary measurements took place on an almost zonal section throughout the Mediterranean Sea, following the principle and requirements of the global GOSHIP repeated oceanographic survey program, tailored for the Mediterranean Sea (CIESM, 2012) (GO-SHIP line MED-01).

The present work combines optical and biochemical data for the Mediterranean Sea to: 1) present the spatial distribution of particle-related optical properties and considered biochemical indices in the study area; 2) examine the potential relationship between hydrology and optical properties of main water masses; and 3) explore the associations of optical parameters with PM, and in particular its organic forms, to gain new insights into the main physical and biogeochemical features driving particle dynamics in the oligotrophic Mediterranean Sea.

\section{METHODOLOGY}

\section{Cruise Description and Sampling}

The survey was carried out on board the German $R / V$ Maria S. Merian from March 2nd to April 3rd 2018 (Figure 1). The cruise started at Heraklion, Crete, Greece and ended in Cadiz, Spain (Hainbucher et al., 2020). In total, 136 CTD casts were conducted during the cruise materializing a complete east-to-west Mediterranean transect plus another one in the Ionian Sea. The CTD system used was a Seabird SBE911plus and a Seabird SBE32 carousel equipped with 24/10lt Niskin bottles. Dual sensors for temperature and conductivity were employed. Salinity values were checked against water salinity samples with the help of a Guildline Autosal salinometer in the laboratory. Overall accuracies were within the expected instrument range of salinity. More details for the instruments setup and the sampling 
strategy can be found in Hainbucher et al. (2020). At 62 stations (with depth $<3,000 \mathrm{~m}$ ) the LISST-Deep was deployed along with the rosette system to obtain optical parameters i.e., beam attenuation coefficient, particle volume concentration, particle median diameter, and the slope of PSD. At 15 stations, seawater samples were also collected for the elemental and stable isotopic analysis of carbon and nitrogen of PM.

\section{Beam Attenuation Coefficient, Particle Volume Concentration and Particle Median Diameter}

Laser diffraction is a method that permits nondestructive in situ measurements of the particle size distribution over a relatively large size range, implemented in Laser in Situ Scattering and Transmissometry (LISST-Deep), an autonomous instrument manufactured by Sequoia Scientific Inc., to measure particle size distribution and the beam attenuation coefficient in the deep sea (Agrawal and Pottsmith, 2000). LISST-Deep derived variables are the beam attenuation coefficient due to particles $\left(c_{p}\right.$ at $670 \mathrm{~nm}^{-1} \mathrm{~m}^{-1}$ ), the total particle volume concentration (VC in $\mu \mathrm{L} \mathrm{L}^{-1}$ or ppm), and the particle median diameter $\left(\mathrm{D}_{50}\right.$ in $\left.\mu \mathrm{m}\right)$. A detailed description of the methodology applied is given in the Supplementary Material.

\section{Estimation of Particle Size Distribution Slope, $\xi$}

The PSD slope, $\xi$, provides information on the relative concentration of small to large particles, i.e. steep slopes correspond to higher abundance of small particles and flatter slopes to the opposite; its mathematical description using the power-law model is used most often in marine studies (Buonassissi and Dierssen, 2010; Xi et al., 2014). For the estimation of $\xi$, we followed Xi et al. (2014). Methodological details are given in the Supplementary Material.

\section{Elemental and Stable Isotope Analysis of Carbon and Nitrogen}

For the determination of POC, PN contents and stable isotopic composition $\left(\delta^{13} \mathrm{C}-\mathrm{POC}\right.$ and $\left.\delta^{15} \mathrm{~N}-\mathrm{PN}\right)$, seawater samples $(5-10 \mathrm{~L})$ were collected close to the sea surface, within the maximum of chlorophyll fluorescence and main water masses from 15 stations across the study area (98 samples in total; Figure 1). The POC and PN contents and their stable isotopic composition were determined at the Stable Isotope Facility at the University of California Davis (Davis, CA, United States), using a PDZ Europa ANCA-GSL elemental analyzer coupled to a PDZ Europa 20-20 isotope ratio mass spectrometer (Sercon Ltd., Chesire, United Kingdom). Methodological details are given in the Supplementary Material.

\section{Surface Chl-a Satellite Imagery}

To evaluate the sea surface productivity in the study area for the duration of the cruise, monthly mean and 8 day average sea surface chlorophyll- $a$ concentrations (Chl- $a$ ) were obtained using the Ocean Color (OC) climate record developed by the European Space Agency (ESA) in the framework of its Climate Change Initiative (CCI) activity. Detailed description is given in the Supplementary Material.

Visualization and Statistical Analysis of Data The spatial distribution of the various optical and geochemical parameters considered herein was visualized by using Ocean Data View - ODV (Schlitzer, 2018). The dataset variables are normally distributed (passed Kolmogorov-Smirnov tests) thus, the determined optical and biochemical parameters, including water depth, were tested on their potential statistical relationships by using 2-tailed Pearson correlation analysis (SPSS statistics software v. 17.0); the data set was divided into western and eastern Mediterranean data points and Otranto Strait data points, since those regions exhibited considerable differences in the spatial distribution of the studied parameters (see Discussion below).

\section{RESULTS AND DISCUSSION}

\section{Hydrological Setting}

The Theta-S diagram of the stations sampled during the MSM72 cruise is presented in Figure 2. The profiles have been assigned into four different groups each with different hydrological characteristics. Two profile groups represent stations in the WMed, one sampled from the Gibraltar Strait up to the Sardinia channel and a second one in the Sardinia channel until the Tyrrhenian Sea. Two profile groups represent stations sampled in the EMed, one sampled in the western part of the EMed (mostly in the Ionian Sea), and a second one sampled in the eastern Ionian Sea, Otranto strait, Cretan Passage and Cretan Sea. The reader is referred to the caption of Figure 2 for information about the group color-coding. For further information related to this section, the reader is referred to Astraldi et al. (1999), Wüst (1961), Millot (1999), Malanotte-Rizzoli (2001), Millot and Taupier-Letage (2005), Tanhua et al. (2013), and references therein.

The Mediterranean Sea is a concentration basin where the amount of water lost to the atmosphere through evaporation is larger than the water added into the basin through precipitation and riverine input. In order to balance this water budget deficit, low salinity Atlantic Water (AW) enters the basin through the Gibraltar Strait in the WMed and follows an eastward path towards the Sicily strait, before advancing into the EMed. The low salinity signal of the entering AW surface mass is much stronger close to the entrance point, and whilst it is still evident along its eastward route in the Tyrrhenian and Ionian Seas, salinity is increased. Finally, in the eastern part of the EMed, surface AW masses are transformed into a high salinity, warm surface water mass known as Levantine Surface Water (LSW), which is the most saline surface mass of the Mediterranean Sea. Levantine Intermediate Water (LIW) formed mainly in the Levantine Sea during winter is a saline water mass with a density not high enough to penetrate the Mediterranean deep layers. Thus, it is usually traced as a local salinity maximum at 


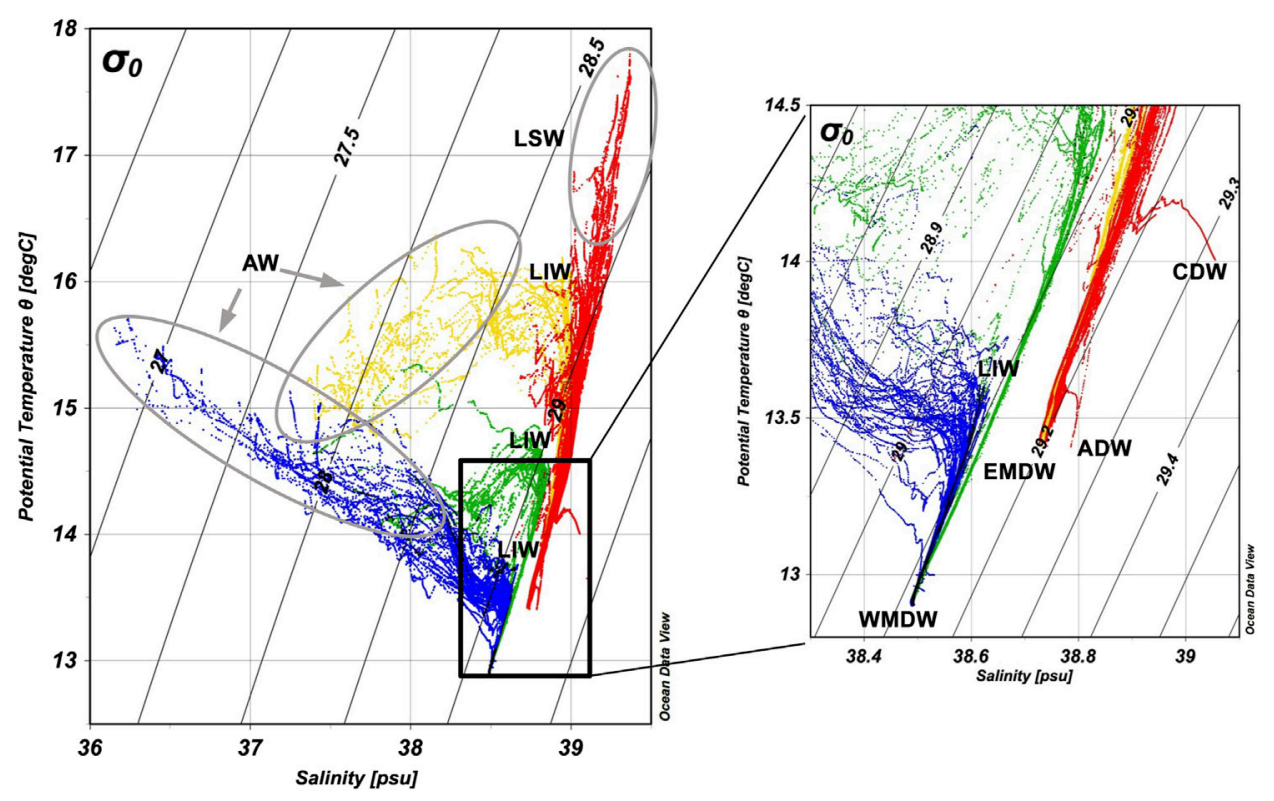

FIGURE 2 | Theta-S diagram of the stations sampled during the MSM72 cruise. The profiles have been grouped into four categories assigning different colors to different hydrological characteristics. Blue and green profiles represent stations in the WMed: Gibraltar Strait up to the Sardinia channel; Sardinia channel and the Tyrrhenian Sea, respectively. Yellow and red profiles represent stations sampled in the EMed: western part of the EMed (mostly in the lonian Sea); east lonian Sea, Otranto strait, Cretan Passage and Cretan Sea, respectively. The abbreviations of the identified main water masses are defined in the text.

intermediate depths. In general, intermediate waters in the Mediterranean are defined as those occupying the layer between $\sim 150$ and $600 \mathrm{~m}$. After formation, LIW follows a path opposite to that of AW, and finally exits the Mediterranean through the Gibraltar Strait below the AW layer. This dual flow regime constitutes the upper thermohaline conveyor belt that runs throughout the whole Mediterranean Sea.

Close to the formation sites, LIW masses cannot be clearly observed, as the shallower layers in the absence of AW are more saline than LIW (Figure 2). However, along its westward route, local salinity LIW core maxima can easily be discerned. From the Ionian Sea, through the Tyrrhenian basin and further on towards Gibraltar, LIW becomes colder and less saline, thus increasing its density $\left(\sigma_{\theta}\right)$ from $\sim 29 \mathrm{~kg} \mathrm{~m}^{-3}$ in the Ionian Sea to $\sim 29.05 \mathrm{~kg} \mathrm{~m}^{-3}$ in the Tyrrhenian and $\leq 29.10 \mathrm{~kg} \mathrm{~m}^{-3}$ in the western part of the WMed. During this route, LIW core depth increases from 200 to $250 \mathrm{dbar}$ in the Ionian Sea, to $250-300 \mathrm{dbar}$ in the Tyrrhenian, and to 400-500 dbar in the WMed.

The Mediterranean deep water formation areas are different for the west and east sub-basins. The Gulf of Lions in the west and the Adriatic Sea in the east, are the most active formation sources. The deep waters formed are practically isolated by the shallow $(\sim 400 \mathrm{~m})$ strait of Sicily. Hence, East Mediterranean Deep Water (EMDW) is easily distinguishable from West Mediterranean Deep Water (WMDW), as the former is warmer, more saline and denser than the latter. The density $\left(\sigma_{\theta}\right)$ of these two different water masses is $\geq 29.20$ and $<29.15 \mathrm{~kg} \mathrm{~m}^{-3}$ respectively. In the lower part of the Theta-S diagram (Figure 2) blue and green WMed profiles merge as WMDW shares almost the same properties throughout the basin. The same applies to the lower part of the yellow and red EMed profiles, with two exceptions. Firstly, the isolated high temperature, salinity and density, hookshaped profile observed in the red group, is a profile in the Cretan Sea, where deep water density is over $\sigma_{\theta} 29.30 \mathrm{~kg} \mathrm{~m}^{-3}$. This Cretan Deep Water (CDW) mass has stagnated inside the Cretan Sea for the last two decades (Velaoras et al., 2019). Secondly, the profile sampled in the Otranto strait appears to be slightly denser $\left(\sigma_{\theta} \geq 29.24 \mathrm{~kg} \mathrm{~m}^{-3}\right)$ at a depth of 760-900 dbar. This marks the winter-formed Adriatic Deep Water (ADW) which plunges through the shallow Otranto strait towards the Ionian abyssal plain. Between the intermediate and bottom layers (approximately from 700 to $1,600 \mathrm{~m}$ ) of the EMed, a low salinity and oxygen water mass is found called the Transitional Mediterranean Water (TMW). This is the oldest water in the eastern Mediterranean (Stöven and Tanhua, 2014) and is the product of the uplift of deep masses by intrusions of bottom water masses of Adriatic and/or Aegean origin (Velaoras et al., 2019). In the literature (Stöven and Tanhua, 2014; Li and Tanhua, 2020) TMW can be also found as Tracer Minimum Zone (TMZ) due to its low concentration in transient tracers (i.e., CFC-12, $\mathrm{SF}_{6}$ ).

Finally, it should be noted that during the last decades both Mediterranean sub-basins have been subjected to severe overturning circulation changes. In the EMed during the early 1990s a shift in the dominant dense water formation source from the Adriatic to the Aegean Sea was observed. This event is known as the Eastern Mediterranean Transient (EMT) and resulted in the massive export of dense, warm and saline deep waters from the Aegean Sea to the EMed abyssal reservoirs. The Adriatic Sea gradually regained its role as the 

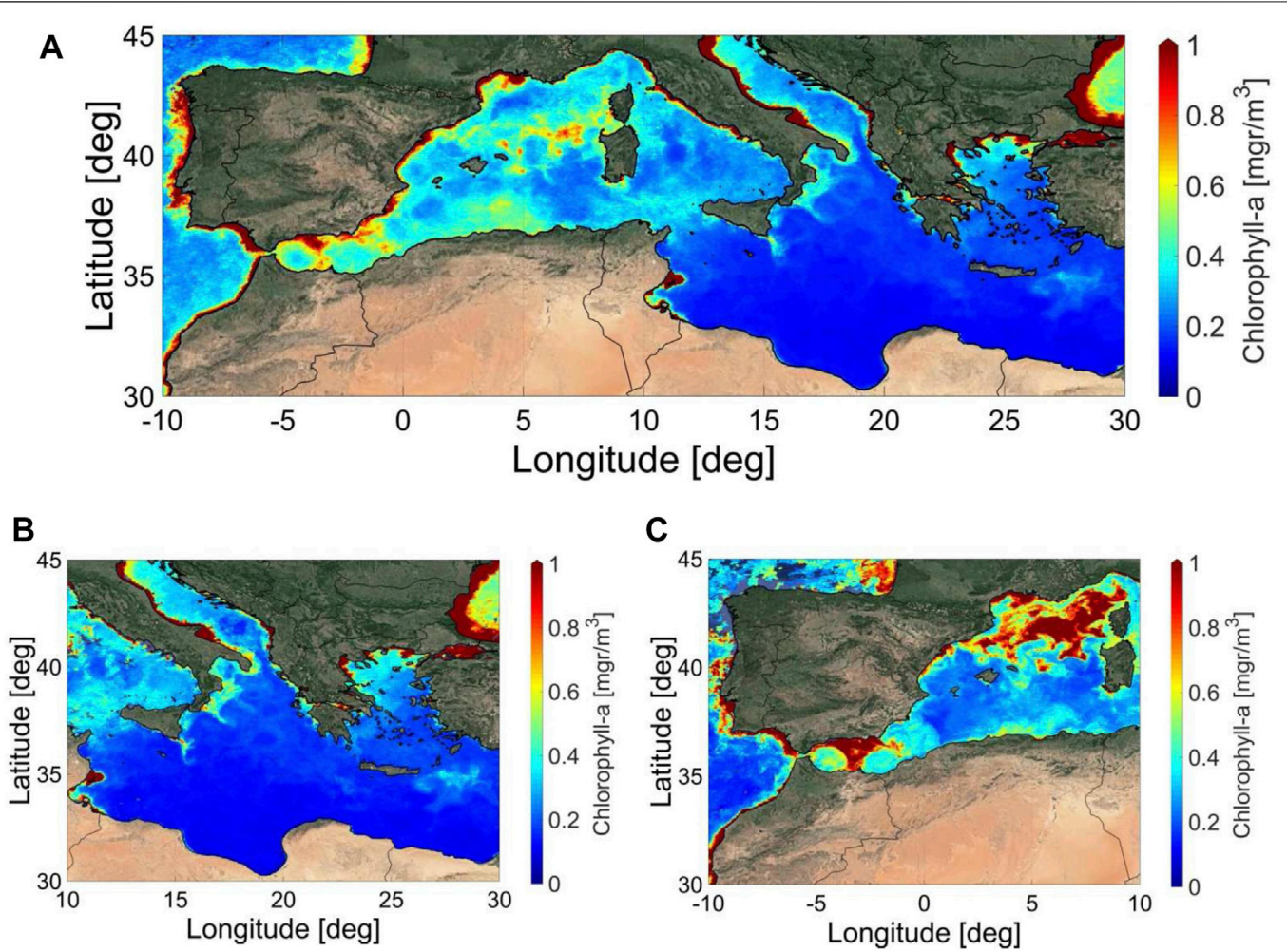

FIGURE 3 | Monthly mean (March 2018) (A) and 8 day average sea surface Chlorophyll-a concentration in the Mediterranean Sea for the first (06-13/03/2018) (B) and second (30/03/2018-06/04/2018-right) (C) part of the MSM72 cruise.

main dense water source of the EMed only after the early 2000s (Roether et al., 2007; Cardin et al., 2015). Between 2004 and 2006 significant dense water formation events were observed in the WMed, producing larger quantities of warmer, saltier and denser deep waters masses than ever before. This event is known as the Western Mediterranean Transition (WMT) and is partly attributed to salinity preconditioning caused by the import from the EMed through the Sicily Strait of intermediate water masses with higher-than-usual salinity due to the preceding EMT event (Schroeder et al., 2016; Schroeder et al., 2017).

\section{Biogeochemical Setting}

The Mediterranean Sea is a semi-enclosed deep basin (maximum depth 5,125 m offshore Peloponnese, Greece, EMed) characterized by oligotrophy, an overall result of low nutrient inputs into the basin (Krom et al., 2014). Nutrient concentrations in the Mediterranean Sea are characterized by a decreasing trend from the oligotrophic WMed to the ultra-oligotrophic EMed (Azov, 1991; Ignatiades et al., 2002). Redfield-deviated (i.e. higher than 16:1) N/P ratios become more pronounced eastwards and are essentially explained by the excess $\mathrm{N}$ over $\mathrm{P}$ in all nutrient sources arriving in the basin via atmospheric deposition (Mara et al., 2009; Markaki et al., 2010) and river discharge (Ludwig et al., 2009; Krom et al., 2010). The large loss of inorganic nutrients, through the inflow of relatively nutrient-depleted Atlantic water at surface layers and the outflow of the underlying nutrient-rich Mediterranean waters through the
Strait of Gibraltar (Béthoux et al., 1998), prevents nutrient accumulation in deep waters, strongly limiting both primary and secondary production and thus particulate matter formation.

Within the Mediterranean, the EMed waters are very transparent and exhibit unique optical characteristics such as very low beam attenuation coefficient $\left(c_{\mathrm{p}}\right)$ values at depths $>200 \mathrm{~m}\left(<0.04 \mathrm{~m}^{-1}\right.$ in the open Ionian Sea $)$, associated with very low particulate matter and particulate organic carbon concentrations (PMC $<100 \mu \mathrm{g} \mathrm{L}^{-1}, \quad$ POC $<40 \mu \mathrm{g} \mathrm{L}^{-1}$, respectively) (Karageorgis et al., 2008; Zaccone et al., 2012; Ortega-Retuerta et al., 2019). Overall, the oligotrophy in combination with the dominance of the microbial food web in the pelagic ecosystem results in low food availability for top predators (Turley et al., 2000; Siokou-Frangou et al., 2002) and low levels of carbon sequestration to depth (Gogou et al., 2014).

Satellite chlorophyll- $a$ concentrations during the MSM72 cruise are presented in Figures $\mathbf{3 A - C}$. Figure $\mathbf{3 A}$ shows the monthly mean average sea surface chlorophyll- $a$ concentration in the Mediterranean Sea for March 2018, while Figures 3B,C shows the 8 day average sea surface chlorophyll- $a$ concentrations in the Mediterranean Sea for the first (06-13/03/2018) and second (30/ 03/2018-06/04/2018) legs of the MSM72 cruise, which corresponds to the sampling periods in the EMed and WMed Mediterranean sub-basins, respectively.

According to this, during the MSM72 cruise, a west-to-east, as well as a north-to-south gradient in oligotrophy, was observed in the two sub-basins (Figures $\mathbf{3 A - C}$ ), which is in accordance with 


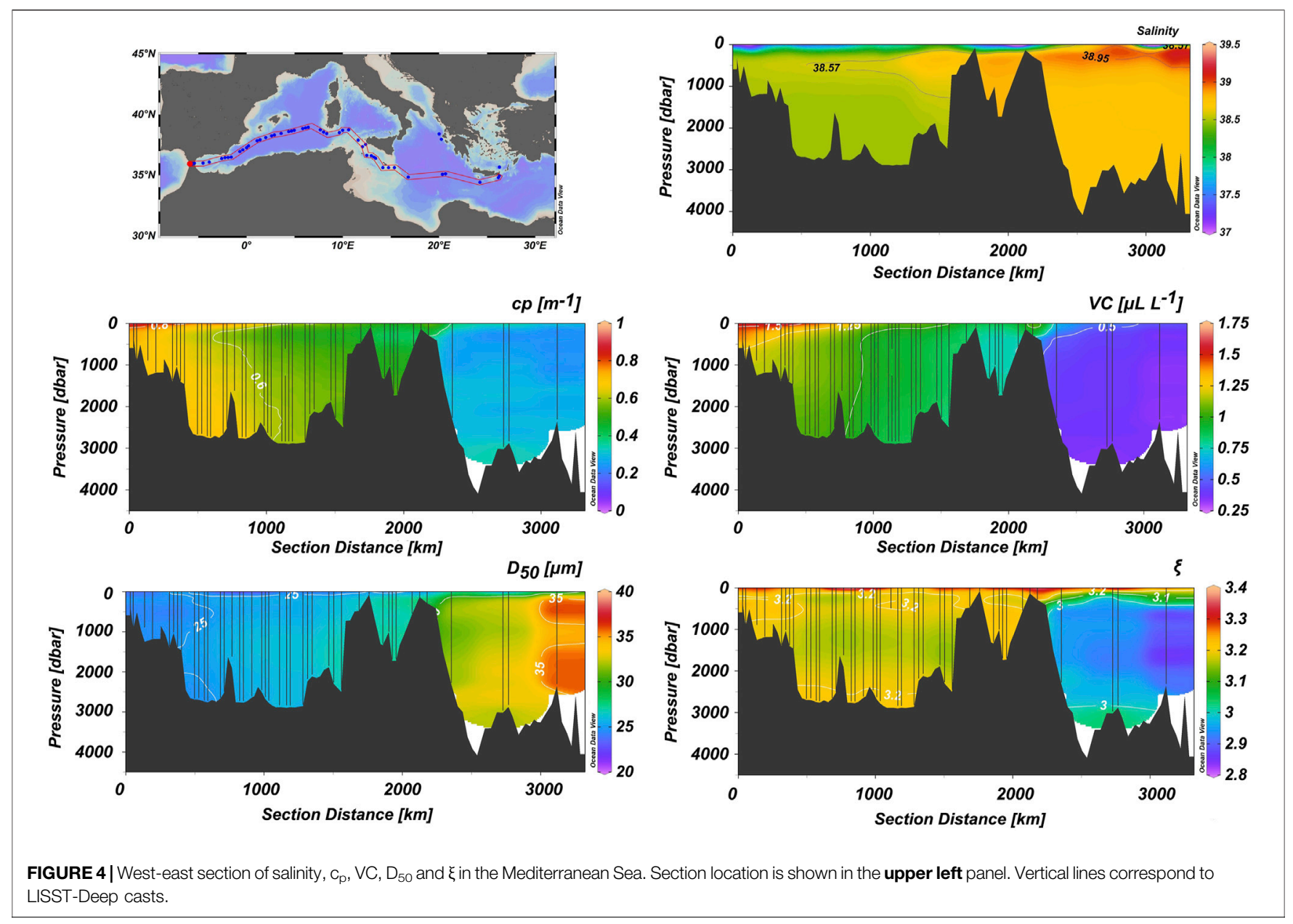

what has previously been described for the different Mediterranean bioregions (D'Ortenzio and Ribera d'Alcalà, 2009; Mayot et al., 2016). In these studies, the biogeography of the Mediterranean Sea and the seasonal cycle of the surface biomass were characterized in different areas of the basin by analyzing 10-year satellite surface Chl- $a$ concentrations, and the results showed that the Mediterranean sub-regions have varying physical, chemical and biological forcing factors. However, it is important to note that surface Chl- $a$ as seen by satellites, is not representative of the total phytoplankton biomass in the Mediterranean waters, i.e. subsurface phytoplankton dynamics, in particular those associated with the Deep Chlorophyll Maximum (DCM) at the base of the upper mixed layer (Barbieux et al., 2019; D'Ortenzio et al., 2021) could be highly underestimated.

\section{Spatial and Vertical Variations of Particulate Matter Optical Properties}

A west-east section of $c_{p}, V C, D_{50}$, and $\xi$ distribution in the study area is presented in Figure 4, and Table 1 summarizes the range and mean values in the entire Mediterranean as well as the considered sub-regions, i.e., Gibraltar and Algerian Basin, Sardinia and Tyrrhenian Sea, Sicily Strait and western Ionian
Sea, Otranto Strait, Ionian Sea (excluding the Otranto Strait) and the Cretan Sea. The beam attenuation coefficient, $c_{p}$, clearly exhibits higher values throughout the water column in the WMed, especially in the upper $\sim 100 \mathrm{~m}$, and progressively the $c_{p}$ signal decreases towards the east, at first towards the Sicily strait, and then it becomes very weak in the EMed, with values $<0.1 \mathrm{~m}^{-1}$. The cruise average $c_{\mathrm{p}}$ was $0.53 \pm 0.17 \mathrm{~m}^{-1}$ and the highest values were recorded in the upper $\sim 200 \mathrm{~m}$ of the westernmost part of the section $\left(>1.0 \mathrm{~m}^{-1}\right)$. The maximum value of $1.77 \mathrm{~m}^{-1}$ was recorded near-bottom in the Otranto strait, and the minimum $\left(0.025 \mathrm{~m}^{-1}\right)$ in the intermediate waters east of Crete.

The particle volume concentration, VC, along the section shows similar characteristics to $c_{p}$, with higher values in the WMed and progressively lower values towards the central Mediterranean and the EMed. It exhibits an average of $0.89 \pm$ $0.31 \mu \mathrm{L}^{-1}$ in the entire Mediterranean Sea. Similarly to $c_{\mathrm{p}}$, the maximum value occurs near-bottom in the Otranto strait $\left(3.7 \mu \mathrm{L}^{-1}\right)$, whereas the minimum value appears south of Crete $\left(0.33 \mu \mathrm{L}^{-1}\right)$; overall, we observe a higher abundance of particles in the WMed and a scarcity of particles in the EMed.

Furthermore, the particle median diameter $D_{50}$, in the Mediterranean shows an average of $27 \pm 3 \mu \mathrm{m}$ (particle size was estimated in the range $1.25-92.6 \mu \mathrm{m}$; see Supplementary 
TABLE 1 | Ranges and mean values of the determined optical and biochemical parameters considered in this study in the entire Mediterranean Sea as well as in the various considered sub-regions, i.e., Gibraltar/Algerian Basin (stations 94-137), Sardinia/Tyrrhenian Sea (stations 75-93), Sicily Strait/western lonian Sea (stations 50-72), Otranto Strait (stations 39-42), lonian Sea (stations 7-50 excluding the Otranto Strait) and the Cretan Sea (station 2). Within each of the considered sub-regions mean values of all parameters are also reported for the identified main water masses. The abbreviations of the identified main water masses are defined in the text. "Inter" signifies intermediate water masses regardless of their origin (LIW, CIW, etc.).

\begin{tabular}{|c|c|c|c|c|c|c|c|c|c|c|c|c|}
\hline \multirow[t]{2}{*}{ Area } & \multirow{2}{*}{$\begin{array}{l}\text { Water } \\
\text { mass }\end{array}$} & \multicolumn{6}{|c|}{ Biochemicals } & \multicolumn{5}{|c|}{ Optics } \\
\hline & & $\begin{array}{c}\text { POC } \\
\left(\mu \mathrm{mol} \mathrm{L}^{-1}\right)\end{array}$ & $\begin{array}{c}\mathrm{PN} \\
\left(\mu \mathrm{mol} \mathrm{\textrm {L } ^ { - 1 }}\right)\end{array}$ & $\begin{array}{c}\delta^{13} \mathrm{C}-\mathrm{POC} \\
(\%)\end{array}$ & $\begin{array}{c}\delta^{15} \mathrm{~N}-\mathrm{PN} \\
(\% \circ)\end{array}$ & $\begin{array}{c}\text { POC/ } \\
\text { PN }\end{array}$ & $n$ & $\begin{array}{c}c_{p} \\
\left(m^{-1}\right)\end{array}$ & $\begin{array}{c}\text { VC } \\
\left(\mu \mathrm{L}^{-1}\right)\end{array}$ & $\begin{array}{c}D_{50} \\
(\mu \mathrm{m})\end{array}$ & $\xi$ & $n$ \\
\hline \multirow{7}{*}{ Gibraltar-Algerian Basin } & Surface & 6.02 & 0.79 & -25.80 & 2.14 & 7.68 & 3 & 0.69 & 1.31 & 24 & 3.26 & 2,621 \\
\hline & $\mathrm{DCM}$ & 4.07 & 0.72 & -25.11 & 2.71 & 6.19 & 2 & 0.66 & 0.53 & 25 & 3.23 & 402 \\
\hline & Inter & 1.81 & 0.42 & -27.86 & 3.72 & 7.06 & 3 & 0.60 & 1.12 & 25 & 3.19 & 5,564 \\
\hline & WMDW & 1.62 & 0.36 & -28.16 & 4.35 & 6.55 & 9 & 0.63 & 1.02 & 25 & 3.18 & 17,228 \\
\hline & Max (all) & 7.11 & 1.05 & -24.45 & 5.85 & 10.4 & 17 & 1.56 & 2.78 & 29 & 3.76 & 25,815 \\
\hline & Min (all) & 1.17 & 0.12 & -29.87 & 1.88 & 1.9 & 17 & 0.30 & 0.88 & 19 & 3.10 & 25,815 \\
\hline & $\begin{array}{l}\text { Average } \\
\text { (all) }\end{array}$ & 2.72 & 0.50 & -27.33 & 3.62 & 6.8 & 17 & 0.63 & 1.07 & 25 & 3.19 & 25,815 \\
\hline \multirow[t]{7}{*}{ Sardinia-Tyrrhenian Sea } & Surface & 4.45 & 0.77 & -26.0 & 2.85 & 6.07 & 2 & 0.54 & 0.99 & 25 & 3.25 & 800 \\
\hline & DCM & 3.86 & 0.52 & -25.0 & 1.90 & 7.39 & 1 & 0.53 & 1.00 & 25 & 3.23 & 145 \\
\hline & Inter & 2.07 & 0.22 & -28.1 & 5.92 & 9.57 & 3 & 0.49 & 0.91 & 26 & 3.20 & 1,705 \\
\hline & WMDW & 1.87 & 0.20 & -27.7 & 6.43 & 9.57 & 8 & 0.55 & 0.88 & 26 & 3.17 & 5,250 \\
\hline & Max (all) & 5.55 & 1.06 & -25.02 & 8.10 & 11.0 & 14 & 0.82 & 1.31 & 31 & 3.42 & 7,900 \\
\hline & Min (all) & 1.30 & 0.16 & -28.87 & 1.90 & 5.2 & 14 & 0.31 & 0.72 & 23 & 3.03 & 7,900 \\
\hline & $\begin{array}{l}\text { Average } \\
\text { (all) }\end{array}$ & 2.42 & 0.32 & -27.33 & 5.41 & 8.9 & 14 & 0.54 & 0.90 & 26 & 3.18 & 7,900 \\
\hline \multirow{8}{*}{$\begin{array}{l}\text { Sicily Strait-Western } \\
\text { Ionian Sea }\end{array}$} & Surface & 4.71 & 0.57 & -26.28 & 3.05 & 8.43 & 2 & 0.45 & 0.81 & 26 & 3.27 & 837 \\
\hline & DCM & 3.86 & 1.15 & -27.31 & 3.35 & 5.96 & 2 & 0.45 & 0.84 & 26 & 3.24 & 133 \\
\hline & Inter & 2.28 & 0.23 & -28.47 & 5.82 & 9.85 & 2 & 0.38 & 0.69 & 28 & 3.14 & 1,527 \\
\hline & TMW & 1.67 & 0.24 & -28.73 & 5.51 & 7.75 & 3 & 0.41 & 0.63 & 29 & 3.22 & 2,189 \\
\hline & WMDW & 1.78 & 0.19 & -28.21 & 6.63 & 9.55 & 5 & 0.34 & 0.46 & 32 & 3.21 & 3,445 \\
\hline & Max (all) & 4.96 & 1.99 & -25.31 & 7.79 & 11.2 & 14 & 0.94 & 1.83 & 33 & 3.51 & 8,131 \\
\hline & Min (all) & 1.56 & 0.15 & -29.58 & 2.02 & 2.4 & 14 & 0.07 & 0.34 & 22 & 2.87 & 8,131 \\
\hline & $\begin{array}{l}\text { Average } \\
\text { (all) }\end{array}$ & 2.54 & 0.40 & -27.96 & 5.29 & 8.5 & 14 & 0.32 & 0.64 & 29 & 3.12 & 8,131 \\
\hline \multirow[t]{7}{*}{ Otranto Strait } & Surface & 5.00 & 0.75 & -26.07 & -0.40 & 6.74 & 4 & 0.33 & 0.55 & 28 & 3.16 & 498 \\
\hline & $\mathrm{DCM}$ & 3.61 & 0.51 & -27.18 & 1.96 & 7.24 & 4 & 0.32 & 0.52 & 29 & 3.01 & 159 \\
\hline & Inter & 2.47 & 0.29 & -27.53 & 4.17 & 9.23 & 8 & 0.32 & 0.53 & 30 & 3.10 & 1,063 \\
\hline & ADW & 2.37 & 0.27 & -27.36 & 3.88 & 9.34 & 8 & 0.47 & 0.76 & 30 & 3.16 & 572 \\
\hline & Max (all) & 7.12 & 1.06 & -25.44 & 6.41 & 13.7 & 24 & 1.78 & 3.70 & 37 & 3.76 & 2,292 \\
\hline & Min (all) & 1.66 & 0.16 & -28.82 & -1.31 & 4.0 & 24 & 0.05 & 0.38 & 19 & 2.92 & 2,292 \\
\hline & $\begin{array}{l}\text { Average } \\
\text { (all) }\end{array}$ & 3.08 & 0.40 & -27.16 & 2.80 & 8.6 & 24 & 0.44 & 0.72 & 29 & 3.13 & 2,292 \\
\hline \multirow[t]{8}{*}{ Ionian Sea } & Surface & 4.37 & 0.55 & -25.46 & 0.56 & 7.99 & 3 & 0.30 & 0.49 & 30 & 3.19 & 687 \\
\hline & DCM & 4.01 & 0.87 & -25.40 & 0.98 & 5.99 & 3 & 0.28 & 0.47 & 30 & 3.17 & 81 \\
\hline & Inter & 1.77 & 0.17 & -27.87 & 5.50 & 10.3 & 3 & 0.23 & 0.40 & 34 & 2.97 & 1,478 \\
\hline & TMW & 1.74 & 0.16 & -27.70 & 5.81 & 11.1 & 6 & 0.27 & 0.38 & 34 & 2.92 & 2,720 \\
\hline & EMDW & 1.88 & 0.17 & -27.83 & 6.13 & 10.9 & 7 & 0.30 & 0.37 & 34 & 2.95 & 1,961 \\
\hline & Max (all) & 5.62 & 1.51 & -24.64 & 7.58 & 12.5 & 22 & 0.76 & 0.69 & 37 & 3.46 & 6,927 \\
\hline & Min (all) & 1.06 & 0.09 & -28.83 & -0.88 & 2.3 & 22 & 0.03 & 0.33 & 24 & 2.83 & 6,927 \\
\hline & $\begin{array}{l}\text { Average } \\
\text { (all) }\end{array}$ & 2.46 & 0.31 & -27.14 & 4.43 & 9.8 & 22 & 0.27 & 0.39 & 34 & 2.97 & 6,927 \\
\hline \multirow[t]{8}{*}{ Cretan Sea } & Surface & 5.26 & 0.67 & -26.40 & 0.20 & 7.83 & 1 & 0.25 & 0.45 & 31 & 3.04 & 97 \\
\hline & $\mathrm{DCM}$ & 3.59 & 0.65 & -26.77 & 3.30 & 5.50 & 1 & 0.27 & 0.43 & 32 & 2.99 & 1 \\
\hline & Inter & 3.03 & 0.51 & -27.10 & 2.67 & 7.11 & 2 & 0.21 & 0.39 & 35 & 2.90 & 207 \\
\hline & TMW & 2.78 & 0.38 & -27.93 & 4.06 & 8.50 & 2 & 0.20 & 0.35 & 34 & 2.95 & 180 \\
\hline & CDW & 1.97 & 0.17 & -28.46 & 2.99 & 11.5 & 1 & - & - & - & - & - \\
\hline & Max (all) & 5.26 & 1.22 & -26.40 & 4.20 & 11.5 & 7 & 0.76 & 0.69 & 36 & 3.18 & 485 \\
\hline & Min (all) & 1.97 & 0.17 & -28.46 & 0.20 & 3.1 & 7 & 0.03 & 0.34 & 28 & 2.86 & 485 \\
\hline & $\begin{array}{l}\text { Average } \\
\text { (all) }\end{array}$ & 3.21 & 0.53 & -27.39 & 2.65 & 7.9 & 7 & 0.23 & 0.39 & 34 & 2.95 & 485 \\
\hline \multirow[t]{3}{*}{ All dataset } & Max & 7.12 & 1.99 & -24.45 & 8.10 & 13.7 & 98 & 1.78 & 3.70 & 37 & 3.76 & 49,361 \\
\hline & Min & 1.06 & 0.09 & -29.87 & -1.31 & 1.9 & 98 & 0.03 & 0.33 & 19 & 2.83 & 49,361 \\
\hline & Average & 2.71 & 0.40 & -27.34 & 4.07 & 8.5 & 98 & 0.53 & 0.41 & 27 & 3.15 & 49,361 \\
\hline
\end{tabular}


Material for details). Its evolution from the west to the east is reversed with respect to the previously discussed parameters. $D_{50}$ exhibits lower values in the WMed up to the Sicily strait, which increases substantially towards the east $(>25 \mu \mathrm{m})$. The minimum value of $\mathrm{D}_{50}$ is recorded in the Otranto Strait $(19 \mu \mathrm{m})$, whereas the largest is found in the EMed, south of Crete $(37 \mu \mathrm{m})$.

Finally, the PSD slope $\xi$, along the section shows similar characteristics to $c_{p}$ and $\mathrm{VC}$ with high values in WMed and lower values in EMed, thus confirming the predominance of relatively smaller particle populations in the western basin over the larger particles dominating the eastern basin. The minimum value is 2.83 at the mid and deep waters of the Ionian Sea; on the other hand, the maximum value is 3.76 in the deepwater of the Otranto Strait. In the WMed, the average $\xi$ is $3.2 \pm 0.1$; the average value in the EMed is $3 \pm 0.1$, whereas the Mediterranean Sea average $\xi$ is estimated at $3.1 \pm 0.1$.

Beam $c_{p}$ values from the present study appear to be high when compared to other data sets from the Mediterranean Sea (cruise average $0.53 \mathrm{~m}^{-1}$ ). Karageorgis et al. (2008) compiled 11 years of transmissometry data from the EMed and reported that the average $\mathrm{cp}$ value in the open sea is $\sim 0.1 \mathrm{~m}^{-1}$, i.e. five-fold lower than the present case. It should be noted however, that absolute $\mathrm{cp}$ values depend highly on the acceptance angle of the transmissometer employed. Boss et al. (2009) concluded that eight different transmissometers' mean attenuation values differ markedly and in a consistent way with instrument acceptance angle: smaller acceptance angles provide higher beam attenuation values. Later, Boss et al. (2018) tested cp obtained from LISST-100X (5 cm pathlength, acceptance angle $0.069^{\circ}$ ) against $\mathrm{cp}$ from a hyperspectral spectrophotometer and transmissometer (ac-s, Sea-Bird Scientific, Bellevue, WA, United States, formerly WET Labs, $25 \mathrm{~cm}$ pathlength, acceptance angle $0.93^{\circ}$ ) and found particulate beam attenuation coefficients to be well correlated, with LISST values being slightly larger. LISST's cp values, because of the very small-angle transmissometer employed, would be higher than the ones measured with conventional instruments. In that respect, direct cp comparisons should be avoided, with the exception of $c p$ variation studies conducted in a relative manner.

Data for LISST-Deep derived parameters VC, D50, and occasionally $\xi$, presented in the current study represent a $\sim 30 \%$ increase relative to that available in the literature (Karageorgis et al., 2012; Karageorgis et al., 2014; Karageorgis et al., 2017b; Parinos et al., 2017; Turner et al., 2017; Leroux et al., 2018). A substantial amount of data have been previously reported with LISST-100X, i.e. the 'shallow' version of the instrument, operating up to $300 \mathrm{~m}$ depth (Mikkelsen et al., 2006; Barone et al., 2015; White et al., 2015; Yamada et al., 2015; Many et al., 2016; Qiu et al., 2016).

Literature mean VC values from the coastal and shallow (10-12 m depth) Adriatic Sea were two orders of magnitude higher than our measurements (Mikkelsen et al., 2006). In the northwestern Mediterranean, Gulf of Lions, VC average values in the vicinity of the Rhône River plume decreased progressively (Many et al., 2016) in the offshore direction. The latter notion is further strengthened by the observations of Leroux et al. (2018), who reported $\mathrm{VC}$ values well below $1 \mu \mathrm{L}^{-1}$ in the open northwestern Mediterranean. In the open Ionian and Levantine Seas, Karageorgis et al. (2012) reported mean VC values in the range $0.29-0.30 \mu \mathrm{L}^{-1}$.

The mean D50 literature values for the coastal Adriatic Sea varied from 112 to $291 \mu \mathrm{m}$, much higher than the values reported here. With respect to the Gulf of Lions, in the northwestern Mediterranean Sea, Many et al. (2016) reported PSD in the range of $30-200 \mu \mathrm{m}$ offshore the Rhône River; it should be noted, however, that those values were derived from a combination of LISST-100X and LISST-HOLO instruments thus covering a wider particle size range, including micro-aggregates or macroaggregates. In the open northwestern Mediterranean Sea, Leroux et al. (2018) identified particle populations in the range of $2-109 \mu \mathrm{m}$ that were attributed to river-derived fine silts and microflocs. In the Ionian, Aegean, and Levantine Seas, D50 varied between 86 and $88 \mu \mathrm{m}$ (note that the latter D50 values have been estimated using different methodological assumptions; Karageorgis et al., 2012). The aforementioned literature excerpts, as well as the MSM72 new data, exemplify the pronounced variety of particle sizes encountered in the marine environment of the Mediterranean Sea, resulting from the interplay of numerous biogeochemical processes, and thus enhancing the complexity of the particle pool and its composition dynamics.

With respect to the PSD slope $\xi$, very little information exists for the Mediterranean Sea. Many et al. (2016) estimated the spectral PSD slope $\gamma$ from backscattering measurements and reported values in the range of $0.3-0.7$, approximately corresponding to $\xi$ values 3.3-3.7, thus similar to the MSM72 cruise values. Another example of $\xi$ estimates from the north Aegean Sea (Karageorgis et al., 2017a) reports higher values varying from 3.46 to 4.86 which corresponds to smaller particle populations than the present study. In most oceanic observations $\xi$ values range from 2.5 to 5 (Boss et al., 2001; Kostadinov et al., 2012), which, according to our measurements, is the case for the WMed and the EMed as well. Nevertheless, the PSD slope is highly dependent on: 1) the method of calculation; 2) the size range used, and 3) the existence or not of large deviations from the power law distribution. Regardless of methodological differences, the present data set on PSD slope $\xi$ in the Mediterranean Sea indicates that there exists a substantial difference between the small particle abundance in the WMed in comparison to the larger particle populations in the EMed. The potential causes of this consistent pattern will be investigated hereafter using the biochemical data set obtained during the cruise.

\section{Spatial and Vertical Variations of Particulate Organic Carbon \& Particulate Nitrogen Contents and Their Stable Isotopic Composition}

A west-east section of POC and PN contents and their isotopic composition in the study area is presented in Figure 5, while as in the case of optical properties above, Table 1 summarizes their ranges and mean values in the entire Mediterranean as well as in the various sub-regions considered here. POC and PN concentrations in the study area, considering the entire water 

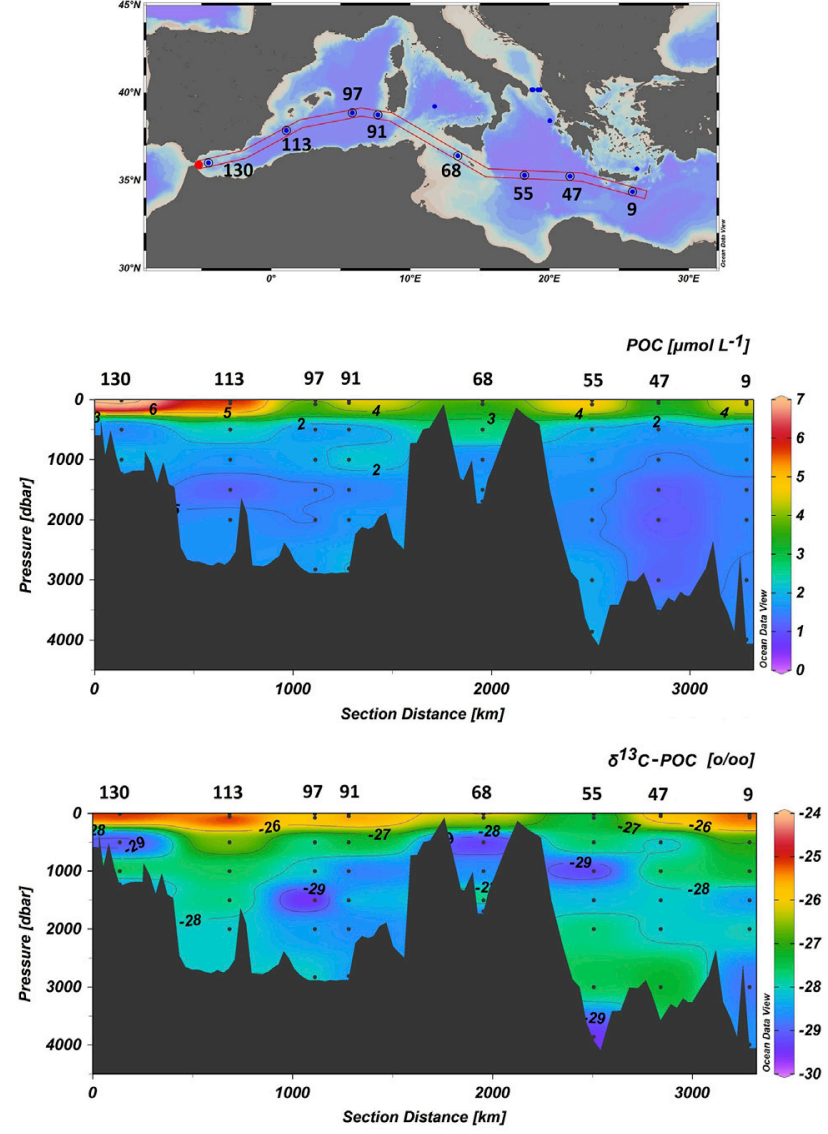
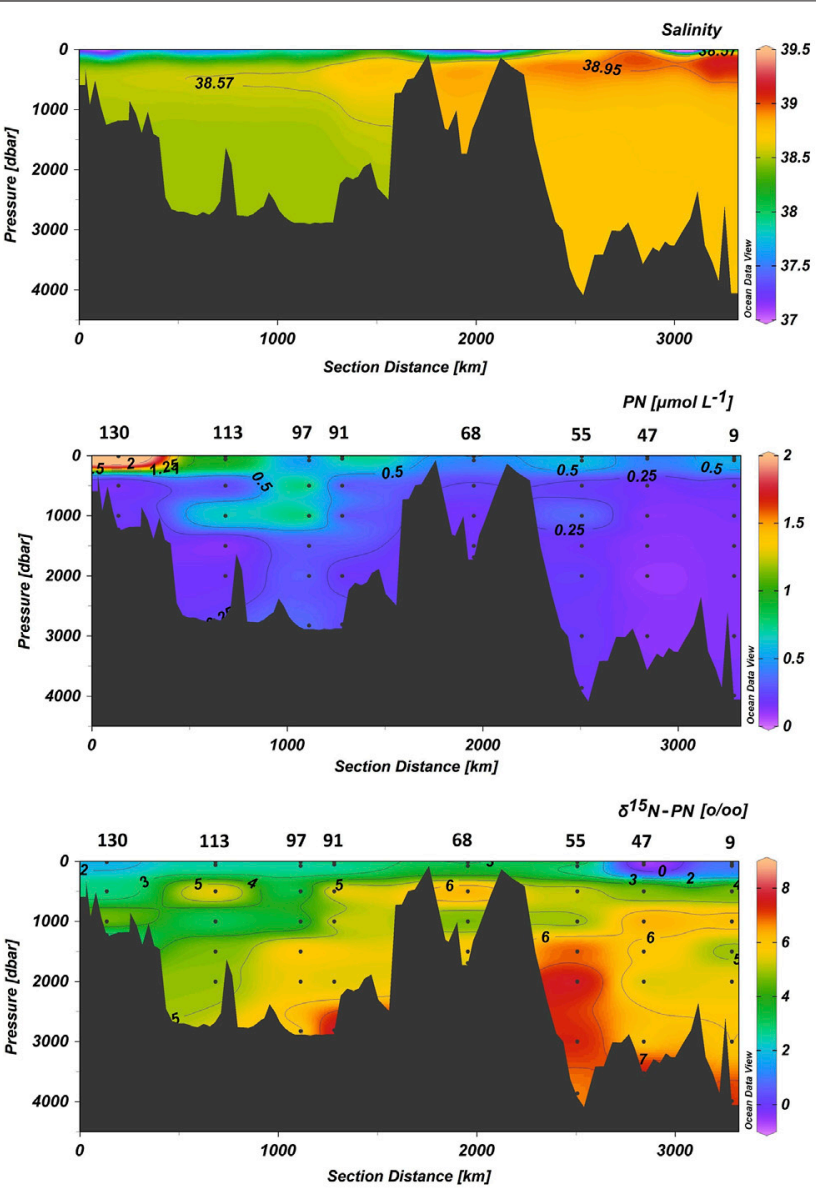

FIGURE 5 | West-east section of salinity, POC and PN contents, $\delta^{13} \mathrm{C}-\mathrm{POC}$ and $\delta^{15} \mathrm{~N}-\mathrm{PN}$ values in the Mediterranean Sea. Section location is shown in the upper left panel. Dots correspond to the sampled depths.

column, ranged from 1.06 to $7.12 \mu \mathrm{mol} \mathrm{L}^{-1}, 2.71 \pm 1.40 \mu \mathrm{mol} \mathrm{L}^{-1}$ on average, and from 0.09 to $1.99 \mu \mathrm{mol} \mathrm{L}-1,0.40 \pm 0.32 \mu \mathrm{mol} \mathrm{L}^{-1}$ on average, respectively. Consequently, the POC/PN molar ratio ranged from 1.9 to 13.7 , with an average of $8.5 \pm 2.6$. Higher POC and $\mathrm{PN}$ concentrations were consistently recorded within surface waters or the maximum of chlorophyll fluorescence of all stations with the highest values being detected in the Alboran Sea and Algerian Basin while lower concentrations were observed in the eastern Ionian Sea and South Cretan margin (Figure 5; Table 1). Within intermediate and deep water layers of the studied subbasins, POC and PN concentrations gradually decrease exhibiting a rather uniform distribution. The $\mathrm{POC} / \mathrm{PN}$ ratio values exhibited a uniform distribution within surface waters or the maximum chlorophyll fluorescence depth of all stations with an average of $6.9 \pm 0.9$. Within intermediate and deep water layers, POC/PN ratio values increase with higher values, up to 11.5 , being detected in the EMed stations and the Otranto Strait (Table 1).

$\delta^{13} \mathrm{C}$-POC ranged between -28.73 and $-25.02 \%$. Close and Henderson (2020) reported $\delta^{13} \mathrm{C}$-POC values in open oceanic waters that span over a broad range, varying from $-35 \%$ at high latitudes to $-16 \%$ at low-mid latitudes. Less depleted values of $\delta^{13} \mathrm{C}$-POC were recorded within surface waters or the maximum chlorophyll fluorescence depth in all stations. Intermediate and deep water $\delta^{13} \mathrm{C}$-POC values varied between -28.73 and $-27.10 \%$, averaging $-27.89 \%$. Within the considered subregions, $\delta^{13} \mathrm{C}$-POC values in near-surface waters of the WMed are comparable to those recorded within the Ionian Sea in the EMed, while more depleted values are evident within surface waters of the Sicily Strait, Otranto and the Cretan Sea. At deeper water depths, $\delta^{13} \mathrm{C}$-POC values in the WMed, the Ionian Sea and the Cretan Sea average $-27.96 \%$ while in the Sicily Strait $\delta{ }^{13} \mathrm{C}$-POC values average $-28.47 \%$. In the Otranto Strait, more enriched $\delta^{13} \mathrm{C}$-POC values are observed, with the ADW value being -27.36\%o (Table 1; Figure 5).

$\delta^{15} \mathrm{~N}-\mathrm{PN}$ values in our data set spans a range from -1.31 to $8.10 \%$. Depleted values are recorded within surface waters or the maximum of chlorophyll fluorescence in all stations, ranging from -1.31 to $3.35 \%$ o (average $1.88 \%$ ), while enriched $\delta^{15} \mathrm{~N}-\mathrm{PN}$ values are recorded in deeper water layers ranging between 2.67 and $8.10 \%$ (average $4.91 \%$ ). Within the considered sub-regions, $\delta^{15} \mathrm{~N}-\mathrm{PN}$ values in near-surface waters of the WMed averaged $2.40 \%$, in the Sicily Strait averaged $3.20 \%$, while in the Ionian Sea, the Otranto Strait and the Cretan Sea $\delta^{15} \mathrm{~N}-\mathrm{PN}$ values averaged $1.10 \%$, with the minimum value being recorded in 
the surface waters of the Otranto Strait and maximum $\delta^{15} \mathrm{~N}-\mathrm{PN}$ value at the maximum of Chl- $\alpha$ fluorescence depth in the Cretan Sea. In deeper water layers, $\delta^{15} \mathrm{~N}-\mathrm{PN}$ values in the Gibraltar and the Algerian Basin range from 2.63 to $5.85 \%$, averaging $4.18 \%$, while more enriched values are recorded westwards in Sardinia and Sicily Strait, averaging $6.07 \%$, and the Ionian Sea, $5.64 \%$ on average with a maximum of $7.79 \%$ within the EMDW layer in station 55. Less enriched values are evident in the Otranto Strait, where values reaching $1.92 \%$ for $\mathrm{ADW}$ are recorded (Table 1; Figure 5).

The POC and PN contents of PM reported in our study fall within the ranges of previously published data for open Mediterranean Sea waters. POC values up to $16.5 \mu \mathrm{mol} \mathrm{L} \mathrm{L}^{-1}$ have been reported for the top $400 \mathrm{~m}$ of the water column in open Mediterranean waters (Struck et al., 2001), up to $13.8 \mu \mathrm{mol} \mathrm{L}^{-1}$ for near surface waters of the open Levantine Basin (Tanaka et al., 2007; Bar-Zeev et al., 2011), up to $7.2 \mu \mathrm{mol} \mathrm{L}^{-1}$ in epipelagic waters of the open northwestern Mediterranean Sea (Ortega-Retuerta et al., 2017) and up to $9.8 \mu \mathrm{mol} \mathrm{L}^{-1}$ in near surface waters of the north Aegean Sea (Parinos et al., 2017). Zaccone et al. (2012) has reported mean POC values of $2.29,0.60$, and $0.59 \mu \mathrm{mol} \mathrm{L}^{-1}$ in epipelagic, mesopelagic and bathypelagic layers of the WMed, with the corresponding values for the EMed being 1.82, 0.77 and $0.59 \mu \mathrm{mol} \mathrm{L}^{-1}$, respectively. Karageorgis et al. (2018) reported POC values in the range $2.3-11.8 \mu \mathrm{mol} \mathrm{L}^{-1}$ in canyons and open slopes of the southern Cretan margin (EMed), while OrtegaRetuerta et al. (2019), reported POC values ranging from 0.10 to $8.60 \mu \mathrm{mol} \mathrm{L}^{-1}$ along an east-west transect across the Mediterranean Sea. Concerning PN contents, Emeis et al. (2010) have reported similar values in vertical profiles of pelagic stations in the Ionian Sea and NW Levantine Sea as has Struck et al. (2001) for the top $400 \mathrm{~m}$ of the water column in open Mediterranean waters. Pavlidou et al. (2020) reported mean PN contents values of 3.17, 2.40, and $0.94 \mu \mathrm{mol} \mathrm{L}^{-1}$ in epipelagic, mesopelagic and bathypelagic layers, in the NE Ionian Sea. It is noteworthy that POC concentrations encountered in the present study are amongst the lowest values observed in the global ocean, as values $<10 \mu \mathrm{mol} \mathrm{L}{ }^{-1}$ were found only in the open Pacific Ocean and Bermuda in the Atlantic Ocean (Gardner et al., 2006).

Concerning $\delta^{13} \mathrm{C}$-POC, and to the best of our knowledge, there are no previous published data along the entire water column, from the surface to deep waters, across the open Mediterranean Sea. Çoban-Yildiz et al. (2006) reported an $\delta^{13} \mathrm{C}$-POC average value of $-22.9 \%$ in the euphotic zone of the Rhodes Gyre in the Levantine Basin, while Struck et al. (2001) reported an $\delta^{13} \mathrm{C}-\mathrm{POC}$ range between -28.41 and $-24.50 \%$ for the top $400 \mathrm{~m}$ of the water column in open Mediterranean waters. In the case of $\delta^{15} \mathrm{~N}-\mathrm{PN}$, the values reported herein fall within the range of previously published data for open Mediterranean Sea waters. Emeis et al. (2010) reported $\delta^{15} \mathrm{~N}$-PN values averaging $1.3 \pm 0.7 \%$ in the mixed layer and up to $8.1 \%$ in deeper waters of the EMed. In a transect across the Mediterranean Sea, Pantoja et al. (2002) observed a significant west-to-east decrease in the isotopic composition of $\mathrm{PN}$ from the upper $200 \mathrm{~m}$ of the water column. In the western basin, $\delta^{15} \mathrm{~N}-\mathrm{PN}$ averaged $2.7 \pm 1.2 \%$, in contrast to $-0.2 \pm 0.7 \%$ o in the eastern basin. Çoban-Yildiz et al. (2006) reported an $\delta^{15} \mathrm{~N}-\mathrm{PN}$ average value of $2.2 \%$ in the euphotic zone of the Rhodes Gyre in the Levantine Basin. Koppelmann et al. (2009) reported $\delta^{15} \mathrm{~N}-\mathrm{PN}$ values within a range of $0.43-1.19 \%$ in surface waters of the Levantine Basin, while slightly higher values were found in the DCM and mesopelagic and bathypelagic depths, ranging between 6.19 and $8.49 \%$. Struck et al. (2001) reported $\delta^{15} \mathrm{~N}-\mathrm{PN}$ values ranging from 2.64 to $13.7 \%$ for the top $400 \mathrm{~m}$ of the water column in open Mediterranean waters, while finally, Pavlidou et al. (2020) reported mean $\delta^{15} \mathrm{~N}-\mathrm{PN}$ values of $-0.57,2.98$ and $4.18 \%$ in epipelagic, mesopelagic and bathypelagic layers, in the NE Ionian Sea (Nestor site).

\section{Particle Dynamics in the Mediterranean Sea as Inferred From Optical Properties and Biochemical Indices}

In order to gain insights on the relationships between measured optical properties and identified water masses in the Mediterranean Sea, T-S diagrams superimposed with $c_{\mathrm{p}}, \mathrm{VC}$, $\mathrm{D}_{50}$, and $\xi$ information were used (Figure 6). Surface Atlantic waters (AW) are clearly characterized as the most turbid waters in the Mediterranean Sea, with average beam $c_{p}$ of $0.68 \pm 0.01 \mathrm{~m}^{-1}$. On the other hand, TMW constitutes another extreme; one of the lowest observed $c_{p}$ values averaging $0.20 \mathrm{~m}^{-1}$. AW spreading towards the EMed and particularly in the Ionian Sea exhibits moderate beam $c_{p}$ values. Intermediate waters masses as LIW show overall $c_{\mathrm{p}}$ values in-between AW and LSW (average $0.57 \pm$ $0.03 \mathrm{~m}^{-1}$ ), whereas deep water masses have different $c_{p}$ values according to their location. This pattern is closely followed in the case of VC and is inversed for $D_{50}$. Average $D_{50}$ in AW is $25 \pm$ $3 \mu \mathrm{m}$, in LSW $35 \pm 2 \mu \mathrm{m}$, in LIW $28 \pm 4 \mu \mathrm{m}$, whereas the lowest average $\mathrm{D}_{50}$ value of $19 \mu \mathrm{m}$ is observed in ADW. AW in the western basin is characterized by low salinities, relatively high turbidity and VC, low particle size, and higher $\xi$. The highest $\xi$ values (>3.15) are observed within AW in the WMed, which decrease as AW spreads out towards the east. LIW on the other hand, exhibits the smallest $\xi$ values, especially in the EMed.

The differentiation between the WMed and the EMed is also illustrated in the variability of mean differential particle volume V'(D) (see Supplementary Material for definition), $\mathrm{D}_{50}$, and PSD slope $\xi$ (Figure 7). Mean $V^{\prime}(D)$ and $\xi$ are higher in the WMed than in the EMed, whereas the opposite is recorded for mean $\mathrm{D}_{50}$ values. These observations demonstrate that in the EMed particle concentration is overall lower than the WMed, whilst mean particle size increases with depth, suggesting that aggregation processes are active in the EMed.

The results of the correlation analysis of the determined optical and biochemical parameters considered in this study are shown in Supplementary Table 1. POC is significantly and positively correlated with $\mathrm{VC}$, negatively with $\mathrm{D}_{50}$, and positively with $\xi$ in both the WMed and the EMed. The elevated VC, POC, and PN concentrations recorded within surface waters of the WMed stations, highlight the enhanced surface production therein, compared to the EMed, resulting in a higher abundance of particles within the upper water column. POC concentration and $\xi$ are strongly, significantly, and 

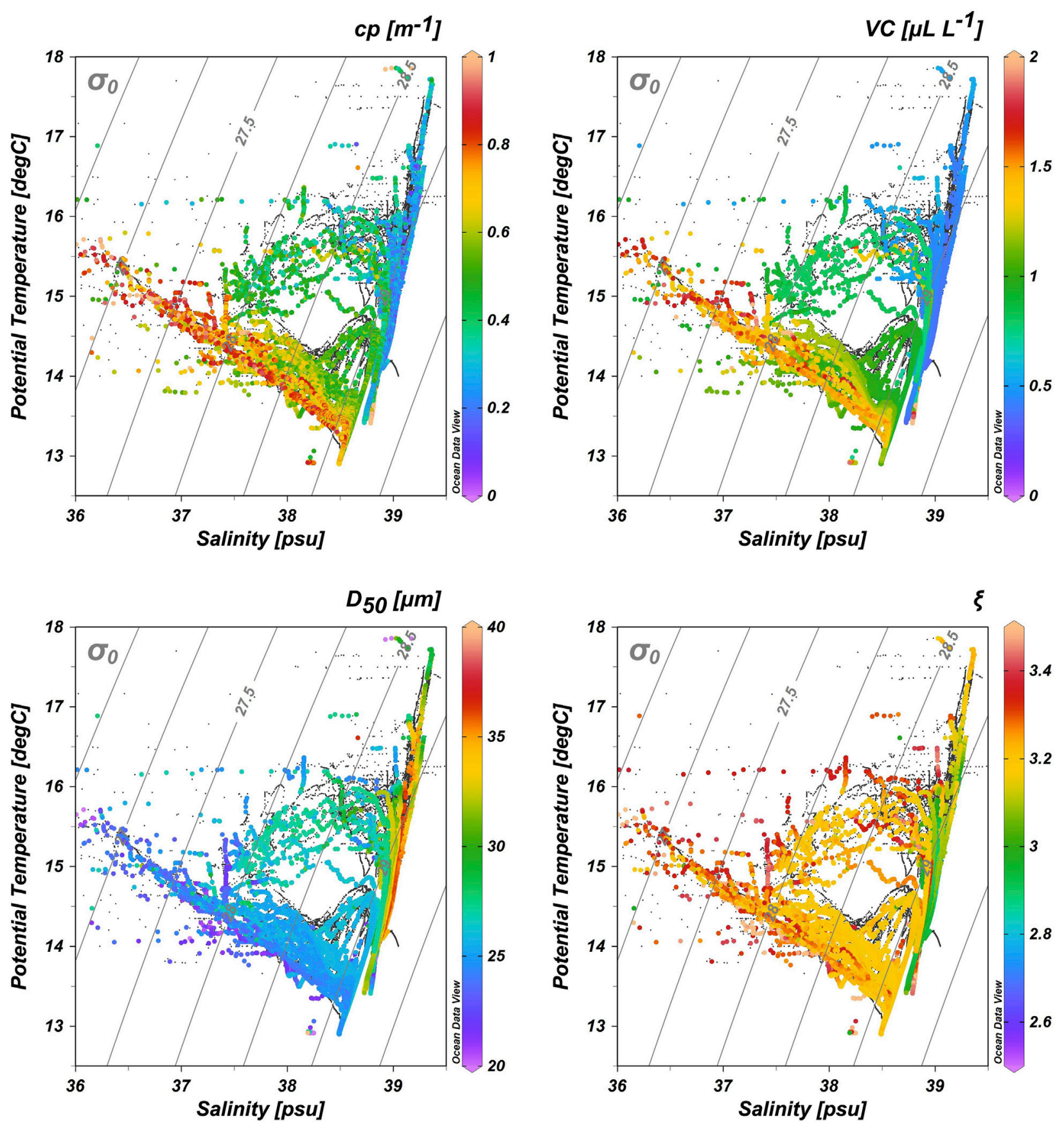

FIGURE 6 | Theta-S diagram of the stations sampled during the MSM72 cruise superimposed with $\mathrm{c}_{\mathrm{p}}, \mathrm{VC}, \mathrm{D}_{50}$ and $\xi$ data. Abbreviations of optical parameters and main water masses are defined in the text.

positively correlated in the Mediterranean Sea, confirming that small particles are POC-rich. Finally, the combined positive correlation of VC with POC concentrations and $\delta^{13} \mathrm{C}$-POC can be attributed to surface productivity.

The positive and significant relationship between $c_{p}$, as a proxy of suspended particle concentration (or turbidity), and POC, has been acknowledged for decades in global ocean studies (Bishop, 1999; Gardner et al., 2006) as well as the Mediterranean Sea
(Loisel et al., 2011); this also holds for the EMed, as demonstrated by Karageorgis et al. (2008) who reported a significant positive correlation between beam $c_{p}$ and POC concentrations. However, it should be mentioned that the level of relationship also depends on the acceptance angle of the transmissometer used, and in the present case, LISST employs a very narrow angle transmissometer, hence correlations may differ substantially. In any case, the observed positive and significant correlation 


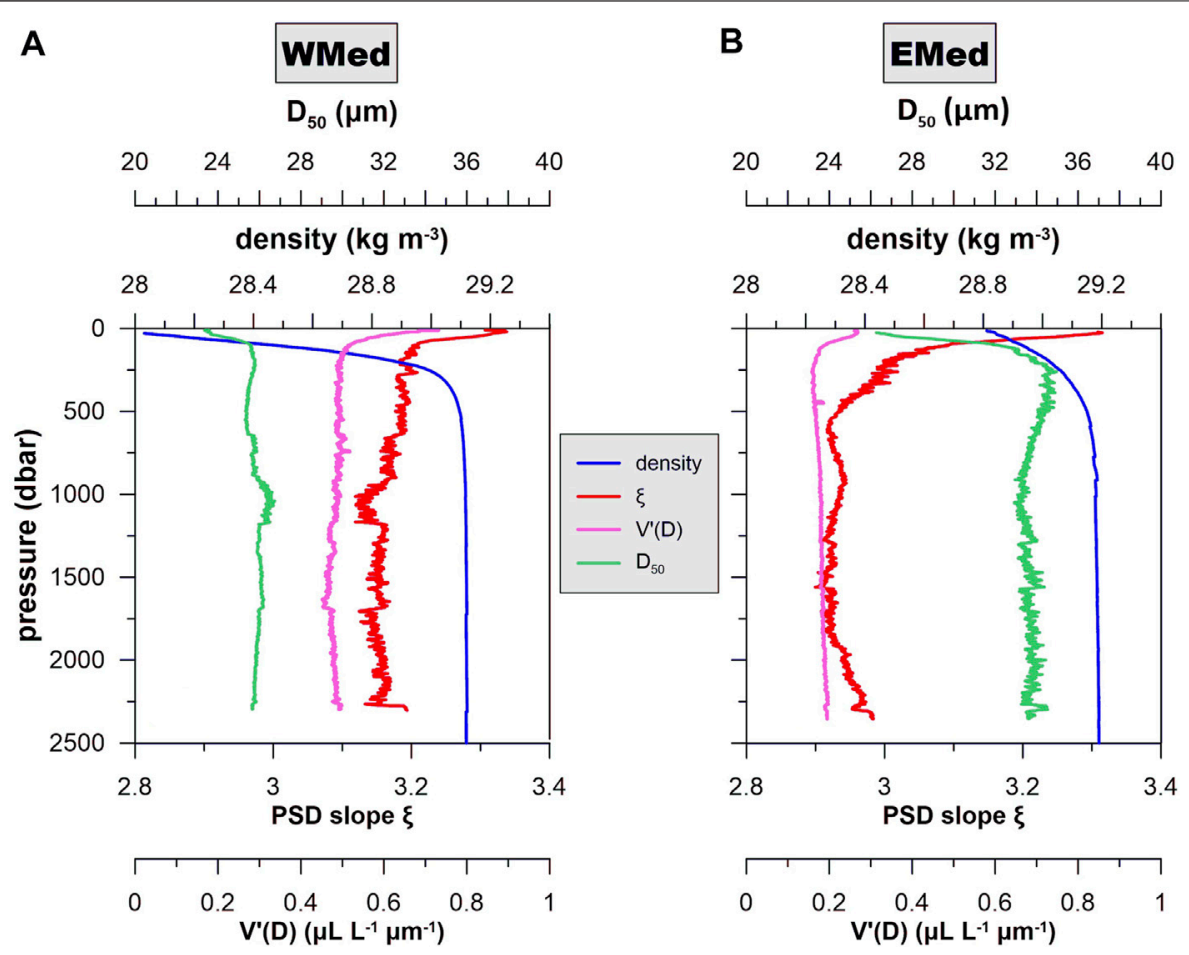

FIGURE 7 | Profiles of mean (smoothed by a 10-point moving average) density, V'(D), $D_{50}$, and PSD slope $\xi$ for the WMed (A) and EMed (B). Differential particle volume $V^{\prime}(D)$ in the WMed is almost double in the WMed than in the EMed. Mean $\xi$ in the WMed is overall higher than the EMed demonstrating the presence of larger particle pools below $\sim 500 \mathrm{~m}$ in the latter, corresponding at a mean $D_{50}$ of $\sim 35 \mu \mathrm{m}$.

( $r=0.613, p=0.002)$ in the WMed highlights the predominance of organic particles in the water column, whereas this relationship weakens in the EMed $(r=0.613, p=0.002)$ probably due to: 1$)$ the narrow acceptance angle of LISST's transmissometer resulting in small sampled water volume (Boss et al., 2009), in combination with the extreme scarcity of particles observed in the EMed, and 2) the presence of generally larger particles in the EMed, greater than the $0.5-20 \mu \mathrm{m}$ range, where most of the light attenuation and scattering occurs, and is detected by transmissometers (Gardner et al., 2006).

$\mathrm{D}_{50}$ is significantly positively correlated with water column depth in both the WMed and the EMed (excluding the Otranto Strait) (Supplementary Table 1) likely suggesting that the process of aggregation of PM with increasing depth is probably present in the study area. Interestingly, $\mathrm{D}_{50}$ is significantly positively correlated with $\mathrm{POC} / \mathrm{PN}$ ratio values only within the EMed stations (excluding the Otranto Strait), while a significant correlation of the POC/PN ratio $v s$. depth is also evident $(r=0.422, p=0.02, n=30)$. Various reasons could account for this result. In oligotrophic systems, such as the EMed, a faster and more efficient decomposition of $\mathrm{N}$ versus $\mathrm{C}$ has been highlighted by previous studies (Altabet, 1996; Meador et al., 2010), which could potentially account for the observed elevated POC/PN values with depth. Moreover, in the EMS, a significant proportion of $\mathrm{C}$ fixed by phytoplankton is released to the dissolved phase (Teira et al., 2001; Lagaria et al., 2011; LópezSandoval et al., 2011), leading to the enhanced extracellular release of organic carbon mainly in the form of carbon-rich acidic polysaccharides (Passow, 2002; Gogou and Repeta, 2010; Parinos et al., 2017). The coagulation of this colloidal dissolved organic matter could lead to the formation of extracellular polymeric substances, mainly transparent exopolymer particles (TEP), bearing a $\mathrm{C} / \mathrm{N}$ ratio signature well above Redfield, i.e. mean value $>20$ (Engel and Passow, 2001; Mari et al., 2001). The observed significant positive correlation of $\mathrm{D}_{50} v s \mathrm{POC} / \mathrm{PN}$ ratio vs depth (Supplementary Table 1) could be indicative of the efficiency of aggregation mechanisms within the EMed, with carbon-rich surface active organic particles (i.e. TEPs) acting as "biological glue" for the formation of larger sized aggregates (Bar-Zeev et al., 2011; Parinos et al., 2017; Ortega-Retuerta et al., 2019). In support of this, Martínez-Pérez et al. (2017), recorded a substantial increase of high molecular weight dissolved organic matter (TEP precursors) in a transect spanning from the Atlantic and Gibraltar to the Levantine Sea (from $40-55 \%$ to $68-76 \%$, respectively) thus providing independent evidence of more important aggregation potential in the eastern sub-basin.

The horizontal patterns of $\delta^{15} \mathrm{~N}-\mathrm{PN}$ observed in the mixed layer of the EMed reflect the interplay of isotopically distinct $\mathrm{N}$ sources and the degree of $\mathrm{N}$ utilization during primary production. Extremely low $\delta^{15} \mathrm{~N}-\mathrm{PN}$ values in $\mathrm{NO}_{3}^{-}$replete waters (Hainbucher et al., 2020) at stations 47 and 9 give evidence for diazotrophic $\mathrm{N}_{2}$ fixation or atmospheric $\mathrm{NO}_{\mathrm{x}}$ deposition in the ultra-oligotrophic EMed (Pantoja et al., 2002; Emeis et al., 2010; Moon et al., 2016). Moreover, low values at still 

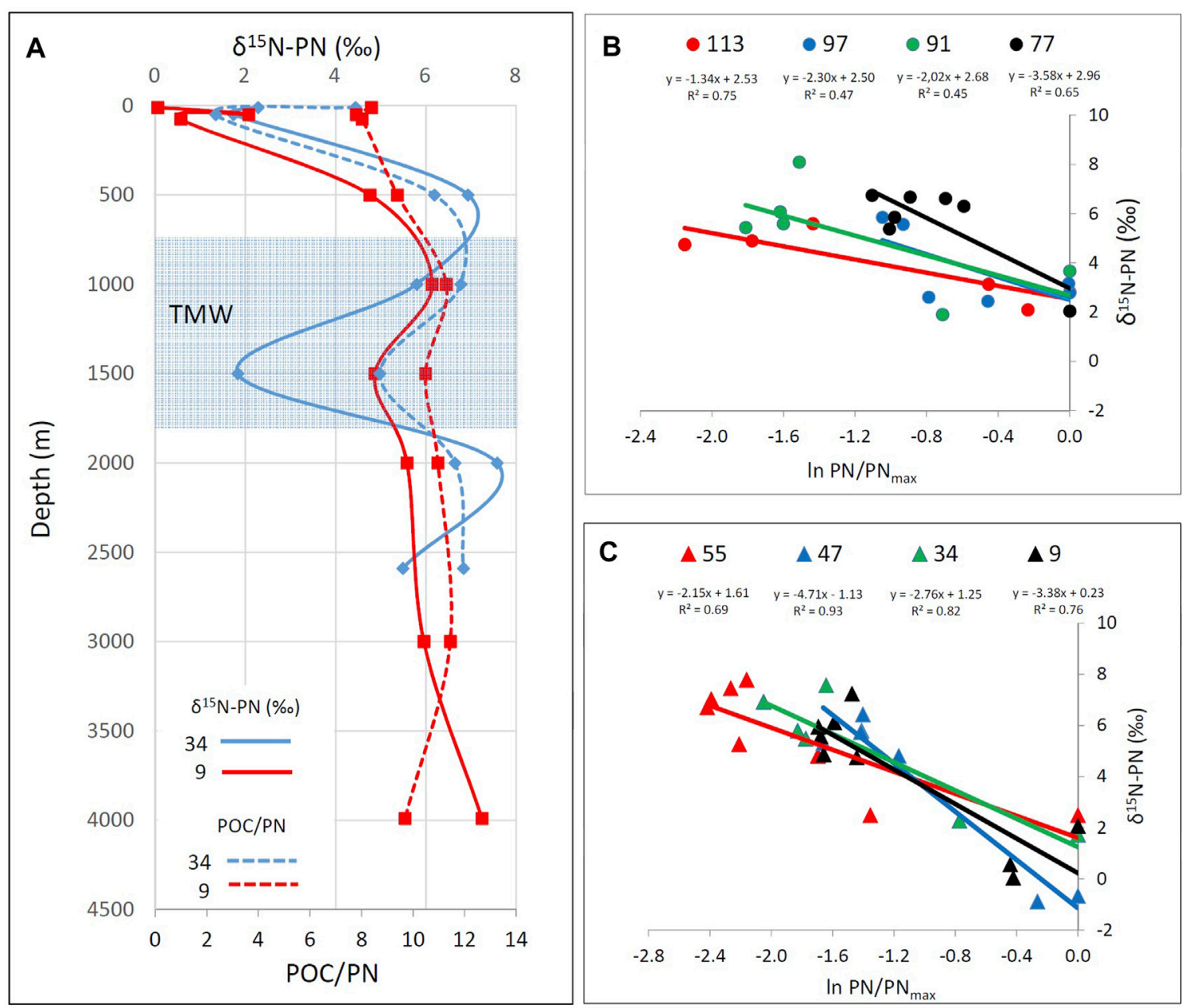

FIGURE 8|Vertical profiles of $\delta^{15} \mathrm{~N}-\mathrm{PN}$ (in \%; solid lines) and POC/PN ratio (dotted lines) for stations 34 (blue lines) and 9 (red lines) showing outliers within the TMW mass (A). PN concentrations per liter, normalized to maximum PN concentrations of surface waters (10 m or DCM depth for each station, except of station 97 for which the max PN values were observed in subsurface waters) vs $\delta^{15} \mathrm{~N}-\mathrm{PN}$ (in \%o) for pelagic stations in the WMed (B) and EMed (C) respectively, indicating Rayleigh-type isotope fractionation. The fractionation factors ${ }^{15} \varepsilon$ calculated from the slope of the logarithmic functions and $r^{2}$ significance in all cases show a clear tendency towards stronger fractionation in the EMed (2.15-4.71\%) compared to the WMed $\left(1.34-3.58 \%\right.$ ). Y-intercepts indicate initial $\delta^{15} \mathrm{~N}$ values of the substrate (from -1.13 to $2.97 \%$ ).

relatively high nitrate levels in the Alboran Sea point towards preferential assimilation of ${ }^{14} \mathrm{~N}$, however, the ambient nitrate most probably had a higher $\delta^{15} \mathrm{~N}$ signature due to its Atlantic origin (Pantoja et al., 2002). Slightly elevated values, in concert with almost depleted $\mathrm{NO}_{3}{ }^{-}$concentrations in the surface waters of remaining stations, imply the assimilation of ${ }^{15} \mathrm{~N}$ enriched $\mathrm{NO}_{3}{ }^{-}$ at the end of a blooming period, but may, to some extent, also reflect the increasing importance of ${ }^{15} \mathrm{~N}$ enriched sources such as Atlantic water and riverine inputs in the WMed as proposed by Struck et al. (2001) and Pantoja et al. (2002).

The striking segregation of relatively depleted $\delta^{15} \mathrm{~N}-\mathrm{PN}$ in the surface or mixed layer waters and enriched values in deep Mediterranean waters has been also observed by Emeis et al. (2010) and Pavlidou et al. (2020). Both attributed the higher $\delta^{15} \mathrm{~N}-\mathrm{PN}$ values in deep waters to the enrichment of residual ${ }^{15} \mathrm{~N}$ during progressive decay of organic matter, whereas the latter for the first time described a systematic relationship to PN concentrations. In contrast to Pavlidou et al. (2020), our EMed data show several (less enriched) outliers in the $\delta^{15} \mathrm{~N}-\mathrm{PN}$ of deep waters. Together with lower POC/PN ratios, these values imply less degraded organic matter (Figure 8A). On the other hand, particle concentrations and particle mean sizes remain stable, in defiance of signals from the surface waters such as a sinking algal bloom. At the same time, nitrate concentrations reach their maxima and $\mathrm{O}_{2}$ concentrations their minima (Hainbucher et al., 2020). Interestingly, all these outliers (even in the Sicily Strait) have been sampled between 500 and $1,500 \mathrm{~m}$ within the TMW. The TMW contains former bottom waters that have been uplifted during the EMT (Stöven and Tanhua, 2014; Velaoras et al., 2019). We consider it possible that fresh organic matter has been released from larger disaggregating particles settling in the bottom water, which remained in the water mass during uplift. 
The high apparent oxygen utilization (AOU) rates recorded before in the mesopelagic and bathypelagic waters of the EMed (Meador et al., 2010; Santinelli et al., 2010) are indicative of exhaustive organic matter recycling, but the remaining (semi-refractory to refractory) organic matter may not be readily available to deep-sea microbes (Rahav et al., 2019) or is highly diluted (Arrieta et al., 2015).

In support of this hypothesis, Sisma-Ventura et al. (2016) reported depleted values of $\delta^{13} \mathrm{C}$-DIC in the LIW and the EMDW of Aegean origin, claiming that isotopically light anthropogenic carbon penetrates the Levantine interior during pronounced convection events such as the EMT. Alternatively, we cannot exclude that lower $\delta^{15} \mathrm{~N}-\mathrm{PN}$ values result from surface waters that have downwelled in the Cretan Sea and the EMed during more recent, extreme winter mixing events (i.e. in 2012 and 2014-2015) (Gačić et al., 2014; Pedrosa-Pàmies et al., 2016; Velaoras et al., 2017; Pedrosa-Pamies et al., 2021).

Similar processes could account for the less enriched values of $\delta^{15} \mathrm{~N}$-PN being observed in some cases at the subsurface layers of the WMed, as a western Mediterranean Transient after the EMT, and extensive downwelling events, have been reported in this sub-basin (Durrieu De Madron et al., 2013; Stöven and Tanhua, 2014; Testor et al., 2018). Finally, we should also mention the possibility that the outliers could give evidence for in-situ aphotic diazotrophic $\mathrm{N}_{2}$ fixation as earlier described for the Mediterranean Sea (Rahav et al., 2013; Benavides et al., 2016; Moisander et al., 2017), although the isotopic fractionation of the processes and sources involved are not yet delineated.

$\delta^{13} \mathrm{C}$-POC values show a surface enrichment-depth depletion profile in all stations. A plausible explanation for the relatively depleted $\delta^{13} \mathrm{C}$-POC values in the marine organic pool of the open Mediterranean Sea can be the contribution of terrestrial organic matter, mainly via atmospheric dry and wet deposition (Gogou et al., 1996; Guerzoni et al., 1999; PedrosaPamies et al., 2021; Stavrakakis et al., 2013). Vertical differences in organic matter quality and quantity are also reflected in lower $\mathrm{N}$ concentrations and the increase of the $\mathrm{POC} / \mathrm{PN}$ ratio in deep waters of all studied sites. Following the approach of Pavlidou et al. (2020), we assume a Rayleigh type isotope fractionation discriminating ${ }^{15} \mathrm{~N}$ during the decomposition of sinking and suspended PN (Möbius, 2013). Evidenced by their data, basic assumptions of Pavlidou et al. (2020) are: 1) PN distribution in the water column is almost solely driven by vertical transport (sinking) from sea surface to bottom waters and 2) additional sources and sinks of PN are negligible. In this case, the strength of fractionation (fractionation factor $\varepsilon^{15}$ ) is expressed by the slope of the logarithmic function of $\delta^{15} \mathrm{~N}-\mathrm{PN}$ vs PN in depth profiles. In our study, fractionation factors calculated vary from 1.34 to $4.66 \%$ (Figures $\mathbf{8 B}, \mathbf{C}$ ) and thus are similar to those published in Pavlidou et al. (2020). In contrast to Pavlidou et al. (2020) excellent correlations that cover the full range between both endmembers, our data show stronger scatter and concentrate on the endmembers with only few exceptions. We explain the scattering by both, the abovementioned outliers in the TMW and by the fact that our sampling sites in the open and deep Mediterranean Sea may be biased by horizontal transport. As correlations in our data set are weaker, we consider the absolute values of fractionation factors with care-nevertheless, a tendency towards stronger fractionation in the EMed can be noted (Figures 8B,C). This could either simply reflect the stronger vertical gradients in $\delta^{15} \mathrm{~N}-\mathrm{PN}$ in the EMed (extremely low in surface waters) or it is plausible as organic matter decomposition is expected to be more complete in the nutrient starving ultra-oligotrophic EMed in comparison to the oligotrophic WMed.

Apart from biogeochemical properties, local mesoscale features' variability and dynamics seem to play an important role in regulating the optical and biochemical characteristics of particulate matter in the study area. Supplementary Figure 1, shows the variability of salinity and beam attenuation coefficient in the Alboran Sea and the Algerian basin. Therein, a sinusoidal variation of salinity is observed, possibly caused by the presence of anticyclonic eddies (Millot, 1999). A similar variation is also observed in the distribution of the beam attenuation coefficient, suggesting that the inherent optical properties of the water masses, and in particular the spatial variability of the beam attenuation coefficient, are largely controlled by mesoscale dynamics.

Interesting optical and biochemical features were also observed in the Otranto Strait which separates the Adriatic and the Ionian Seas (Supplementary Figures 1, 2). Dense waters formed locally in the Adriatic during winter, exit through the bottom of the Otranto Strait, while LIW enters the basin at intermediate layers. The result is a cyclonic flow pattern, with water entry at the eastern part of the Strait and exit through the western part (Kovačević et al., 1999; Yari et al., 2012). Indeed, in the studied section, we observed that waters of Adriatic origin occupy the western Otranto Strait and are characterized by higher $c_{p}$ and VC, and inverse $D_{50}$ values when compared to the LIW waters prevailing in the eastern Otranto Strait. This is accompanied by elevated POC concentrations along with enriched $\delta^{13} \mathrm{C}$-POC, and depleted values for $\delta^{15} \mathrm{~N}-\mathrm{PN}$ at intermediate and near bottom-waters in the western part of the section, likely attributed to the newly formed dense water-bearing the biochemical signature of surface waters that they originated from. Finally, maximum values of $c_{p}$ and $\mathrm{VC}$ are observed near the bottom layers of the central part of the section. This could likely be attributed to surface sediment resuspension due to currents, a commonly observed feature in the world ocean and the Mediterranean Sea as well (Karageorgis and Anagnostou, 2003; Karageorgis et al., 2008; Karageorgis et al., 2012). In support to this, minimum values for $D_{50}$ are observed in the same area, probably due to the fact that resuspension favors the detachment of smaller particles from the seabed.

\section{CONCLUSION}

A data set of beam attenuation coefficient, total particle volume concentration, particle median diameter, and PSD slope $\xi$ up to 
3,000 m depth was obtained across the Mediterranean Sea during cruise MSM72 in March-April 2018, a relatively high productivity period for the region, accompanied by standard CTD, biochemical (POC and PN contents) and isotopic data $\left(\delta^{13} \mathrm{C}\right.$-POC and $\left.\delta^{15} \mathrm{~N}-\mathrm{PN}\right)$ of PM. Surface Atlantic waters were identified as the most turbid waters in the Mediterranean Sea, whilst Transitional Mediterranean Water represents the most transparent water mass. A direct relationship between hydrological parameters, water masses and LISST-derived particle optical properties was observed throughout the Mediterranean Sea. The significant correlation between beam attenuation coefficient $c_{p}$ and POC concentration, consistently observed in the world ocean (Gardner et al., 2006), demonstrates that most particles and particulate organic matter -of marine and/or terrestrial biological origin - predominate in the entire water column of the open Mediterranean Sea. POC concentrations increase inversely with $\mathrm{D}_{50}$ and proportionally with $\xi$, indicating higher organic carbon contents within smaller particle populations. Our data showed substantial differences between the western-central and the eastern sector of the basin, highlighting the transition from mesotrophic to oligotrophic conditions, as well as the overall decrease in suspended particles concentrations. This pattern is observed both in the euphotic zone as well as within the mesopelagic and bathypelagic waters. A predominance of larger particles in the eastern Mediterranean Sea compared to the western Mediterranean Sea was observed, a pattern that is probably associated with more favorable conditions for aggregation in the eastern sub-basin. Basin-wide Rayleigh-type isotope fractionation of $\delta^{15} \mathrm{~N}-\mathrm{PN}$ along the water column and gradients in intensity underline the differences in the trophic characters of the two sub-basins. The presence of relatively depleted $\delta^{15} \mathrm{~N}-\mathrm{PN}$ values in the Transitional Mediterranean Water mass highlights the role changes in circulation patterns have on biogeochemical parameters and the redistribution of particulate matter as a source of nutrients.

\section{DATA AVAILABILITY STATEMENT}

The datasets presented in this study can be found in online repositories. The names of the repository/repositories and accession number(s) can be found below: CTD data: https:// doi.org/10.1594/PANGAEA.905902 (Hainbucher et al., 2020); Laser in situ Scattering and Transmissometry (LISST-Deep) data: https://doi.pangaea.de/10.1594/PANGAEA.934055; Biochemical data of marine PM (POC, PN, $\delta^{13} \mathrm{C}-\mathrm{POC}, \delta^{15} \mathrm{~N}-\mathrm{PN}$ ): https://www. ncei.noaa.gov/data/oceans/ncei/ocads/metadata/0218894.html and https://doi.org/10.1594/PANGAEA.905887.

\section{AUTHOR CONTRIBUTIONS}

SC, CP, AG, DV, SS, and AK conceived the idea, designed the experiment and wrote the manuscript. JM completed the data analysis of nitrogen isotopes and contributed in writing the manuscript. DH, TT, and VC were chief scientist and PIs of the biogeochemistry and physical oceanography groups of the MSM72 cruise, respectively. SC, DV, VC, TT, and DH collected data aboard the cruise. EP and VA contributed the satellite Chl-a data and wrote the relevant text in the manuscript. All authors aided in editing the manuscript.

\section{FUNDING}

This research was supported by the Action "National Network on Climate Change and its Impacts - Climpact" which is implemented under the sub-project 3 of the project "Infrastructure of national research networks in the fields of Precision Medicine, Quantum Technology and Climate Change," funded by the Public Investmen Program of Greece, General Secretary of Research and Technology/Ministry of Development and Investments; and by the "MARine monitoring system of the Hellenic Seas using REmote sensing satellite data and insitu measurements - MARRE" project (T1EDK-02966) financed by the Operational Programme Competitiveness, Entrepreneurship and Innovation (EPAnEK, ESPA 2014-2020) of the Greek Ministry of Economy and Development, and co-funded by the EU (European Regional Development Fund) and by national funds. VA acknowledges support by the ERC Consolidator Grant 2016 D-TECT: "Does dust TriboElectrification affect our ClimaTe?” (grant no. 725698). EP acknowledges support by Greece and the European Union (European Social Fund-ESF) through the Operational Programme "Human Resources Development, Education and Lifelong Learning" in the context of the project "Reinforcement of Postdoctoral Researchers-2nd Cycle" (MIS5033021), implemented by the State Scholarships Foundation (IKY).

\section{ACKNOWLEDGMENTS}

Dr. Laura Bray (Hellenic Centre for Marine Research - Oxbridge English) performed proofreading and linguistic corrections of the manuscript. We sincerely thank the officers and crew of $R / V$ Maria S. Merian for their precious help during the MSM72 cruise. We would also like to thank the Guest Editor Prof. Gerhard Josef Herndl and the two Reviewers, Prof. A.B. Bochdansky and Dr. T.B. Meador, for their precious comments that helped us to significantly improve the manuscript during the revision process.

\section{SUPPLEMENTARY MATERIAL}

The Supplementary Material for this article can be found online at: https:/www.frontiersin.org/articles/10.3389/feart.2021.614703/ full\#supplementary-material 


\section{REFERENCES}

Agrawal, Y. C., and Pottsmith, H. C. (2000). Instruments for Particle Size and Settling Velocity Observations in Sediment Transport. Mar. Geol. 168, 89-114. doi:10.1016/s0025-3227(00)00044-x

Altabet, M. A. (1996). "Nitrogen and Carbon Isotopic Tracers of the Source and Transformation of Particles in the Deep Sea," in Particle Flux in the Ocean. Editors V. Ittekkot, P. Schufer, S. Honjo, and P. J. Depetris (Hoboken, NJ: John Wiley \& Sons), 155-184.

Arrieta, J. M., Mayol, E., Hansman, R. L., Herndl, G. J., Dittmar, T., and Duarte, C. M. (2015). Dilution Limits Dissolved Organic Carbon Utilization in the Deep Ocean. Science 348, 331-333. doi:10.1126/science.1258955

Astraldi, M., Balopoulos, S., Candela, J., Font, J., Gacic, M., Gasparini, G. P., et al. (1999). The Role of Straits and Channels in Understanding the Characteristics of Mediterranean Circulation. Prog. Oceanogr. 44, 65-108. doi:10.1016/s00796611(99)00021-X

Azov, Y. (1991). Eastern Mediterranean-A marine Desert?. Mar. Pollut. Bull. 23, 225-232. doi:10.1016/0025-326x(91)90679-m

Bar-Zeev, E., Berman, T., Rahav, E., Dishon, G., Herut, B., and Berman-Frank, I. (2011). Transparent Exopolymer Particle (TEP) Dynamics in the Eastern Mediterranean Sea. Mar. Ecol. Prog. Ser. 431, 107-118. doi:10.3354/meps09110

Barbieux, M., Uitz, J., Gentili, B., Pasqueron De Fommervault, O., Mignot, A., Poteau, A., et al. (2019). Bio-Optical Characterization of Subsurface Chlorophyll Maxima in the Mediterranean Sea from a Biogeochemical-Argo Float Database. Biogeosciences 16, 1321-1342. doi:10.5194/bg-16-1321-2019

Barone, B., Bidigare, R. R., Church, M. J., Karl, D. M., Letelier, R. M., and White, A. E. (2015). Particle Distributions and Dynamics in the Euphotic Zone of the North Pacific Subtropical Gyre. J. Geophys. Res. Oceans 120, 3229-3247. doi:10.1002/2015jc010774

Benavides, M., Bonnet, S., Hernández, N., Martínez-Pérez, A. M., Nieto-Cid, M., ÁlvarezSalgado, X. A., et al. (2016). Basin-wide N2 Fixation in the Deep Waters of the Mediterranean Sea. Glob. Biogeochem. Cycles 30, 952-961. doi:10.1002/2015gb005326

Béthoux, J. P., Morin, P., Chaumery, C., Connan, O., Gentili, B., and Ruiz-Pino, D. (1998). Nutrients in the Mediterranean Sea, Mass Balance and Statistical Analysis of Concentrations with Respect to Environmental Change. Mar. Chem. 63, 155-169. doi:10.1016/s0304-4203(98)00059-0

Bishop, J. K. B. (1999). Transmissometer Measurement of POC. Deep Sea Res. Oceanogr. Res. Pap. 46, 353-369. doi:10.1016/s0967-0637(98)00069-7

Boss, E., Haëntjens, N., Westberry, T. K., Karp-Boss, L., and Slade, W. H. (2018). Validation of the Particle Size Distribution Obtained with the Laser Iin-Ssitu Scattering and Transmission (LISST) Meter in Flow-Through Mode. Opt. Express 26, 11125-11136. doi:10.1364/oe.26.011125

Boss, E., Slade, W. H., Behrenfeld, M., and Dall'olmo, G. (2009). Acceptance Angle Effects on the Beam Attenuation in the Ocean. Opt. Express 17, 1535-1550. doi:10.1364/oe.17.001535

Boss, E., Twardowski, M. S., and Herring, S. (2001). Shape of the Particulate Beam Attenuation Spectrum and its Inversion to Obtain the Shape of the Particulate Size Distribution. Appl. Opt. 40, 4885-4893. doi:10.1364/ao.40.004885

Bricaud, A., Babin, M., Morel, A., and Claustre, H. (1995). Variability in the Chlorophyll-Specific Absorption Coefficients of Natural Phytoplankton: Analysis and Parametrization. Journal of Geophysical Research Atmospheres 100 (C7), 13,321-13,332. doi:10.1029/95JC00463

Bricaud, A., Morel, A., Babin, M., Allali, K., and Claustre, H. (1998) Variations of light absorption by suspended particles with chlorophyll a concentration in oceanic (case 1) waters: Analysis and implications for bio-optical models. Journal of Geophysical Research Atmospheres 103 (C4), 31,033-31,044. doi:10.1029/98JC02712

Buonassissi, C. J., and Dierssen, H. M. (2010). A Regional Comparison of Particle Size Distributions and the Power Law Approximation in Oceanic and Estuarine Surface Waters. J. Geophys. Res. Oceans 115, C10028. doi:10.1029/2010jc006256

Cardin, V., Civitarese, G., Hainbucher, D., Bensi, M., and Rubino, A. (2015). Thermohaline Properties in the Eastern Mediterranean in the Last Three Decades: Is the basin Returning to the Pre-EMT Situation?. Ocean Sci. 11, 53-66. doi:10.5194/os-11-53-2015

Close, H. G., and Henderson, L. C. (2020). Open-Ocean Minima in $\delta 13 \mathrm{C}$ Values of Particulate Organic Carbon in the Lower Euphotic Zone. Front. Mar. Sci. 7, 540165. doi:10.3389/fmars.2020.540165
Çoban-Yildiz, Y., Altabet, M. A., Yilmaz, A., and Tuğrul, S. (2006). Carbon and Nitrogen Isotopic Ratios of Suspended Particulate Organic Matter (SPOM) in the Black Sea Water Column. Deep-Sea Res. Part Topical Stud. Oceanogr. 53, 1875-1892. doi:10.1016/j.dsr2.2006.03.021

D'Ortenzio, F., and Ribera d'Alcalà, M. (2009). On the Trophic Regimes of the Mediterranean Sea: A Satellite Analysis. Biogeosciences 6, 139-148. doi:10.5194/ bg-6-139-2009

D’Ortenzio, F., Taillandier, V., Claustre, H., Coppola, L., Conan, P., Dumas, F., et al. (2021). BGC-Argo Floats Observe Nitrate Injection and Spring Phytoplankton Increase in the Surface Layer of Levantine Sea (Eastern Mediterranean). Geophys. Res. Lett. 48, e2020GL091649. doi:10.1029/2020gl091649

Durrieu De Madron, X., Guieu, C., Sempéré, R., Conan, P., Cossa, D., D’Ortenzio, F., et al. (2011). Marine Ecosystems' Responses to Climatic and Anthropogenic Forcings in the Mediterranean. Prog. Oceanogr. 91, 97-166. doi:10.1016/ j.pocean.2011.02.003

Durrieu De Madron, X., Houpert, L., Puig, P., Sanchez-Vidal, A., Testor, P., Bosse, A., et al. (2013). Interaction of Dense Shelf Water Cascading and Open-Sea Convection in the Northwestern Mediterranean During Winter 2012. Geophys. Res. Lett. 40, 1379-1385. doi:10.1002/grl.50331

Emeis, K.-C., Mara, P., Schlarbaum, T., Möbius, J., Dähnke, K., Struck, U., et al. (2010). External N Inputs and Internal N Cycling Traced by Isotope Ratios of Nitrate, Dissolved Reduced Nitrogen, and Particulate Nitrogen in the Eastern Mediterranean Sea. J. Geophys. Res. 115, G04041. doi:10.1029/2009jg001214

Engel, A., and Passow, U. (2001). Carbon and Nitrogen Content of Transparent Exopolymer Particles (TEP) in Relation to Their Alcian Blue Adsorption. Mar. Ecol. Prog. Ser. 219, 1-10. doi:10.3354/meps219001

CIESM (2012). "Designing Med-SHIP: a Program for Repeated Oceanographic Surveys." in CIESM Workshop Monograph n. 43, Editor F. Briand (Monaco: CIESM Publisher), 164.

Gačić, M., Civitarese, G., Kovačević, V., Ursella, L., Bensi, M., Menna, M., et al. (2014). Extreme winter 2012 in the Adriatic: An Example of Climatic Effect on the biOS Rhythm. Ocean Sci. 10, 513-522. doi:10.5194/os-10-513-2014

Gardner, W. D., Mishonov, A. V., and Richardson, M. J. (2006). Global POC Concentrations from Iin-Ssitu and Satellite Data. Deep Sea Res. Part Topical Stud. Oceanogr. 53, 718-740. doi:10.1016/j.dsr2.2006.01.029

Gogou, A., and Repeta, D. J. (2010). Particulate-dissolved Transformations as a Sink for Semi-labile Dissolved Organic Matter: Chemical Characterization of High Molecular Weight Dissolved and Surface-Active Organic Matter in Seawater and in Diatom Cultures. Mar. Chem. 121, 215-223. doi:10.1016/ j.marchem.2010.05.001

Gogou, A., Sanchez-Vidal, A., Durrieu De Madron, X., Stavrakakis, S., Calafat, A. M., Stabholz, M., et al. (2014). Carbon Flux to the Deep in Three Open Sites of the Southern European Seas (SES). J. Mar. Syst. 129, 224-233. doi:10.1016/ j.jmarsys.2013.05.013

Gogou, A., Stratigakis, N., Kanakidou, M., and Stephanou, E. G. (1996). Organic Aerosols in Eastern Mediterranean: Components Source Reconciliation by Using Molecular Markers and Atmospheric Back Trajectories. Org. Geochem. 25, 79-96. doi:10.1016/s0146-6380(96)00105-2

Guerzoni, S., Chester, R., Dulac, F., Herut, B., Loÿe-Pilot, M.-D., Measures, C., et al. (1999). The Role of Atmospheric Deposition in the Biogeochemistry of the Mediterranean Sea. Prog. Oceanogr. 44, 147-190. doi:10.1016/s0079-6611(99) 00024-5

Hainbucher, D., Álvarez, M., Astray Uceda, B., Bachi, G., Cardin, V., Celentano, P., et al. (2020). Physical and Biogeochemical Parameters of the Mediterranean Sea During a Cruise with RV Maria S. Merian in March 2018. Earth Syst. Sci. Data 12, 2747-2763. doi:10.5194/essd-12-2747-2020

Honjo, S., Manganini, S. J., Krishfield, R. A., and Francois, R. (2008). Particulate Organic Carbon Fluxes to the Ocean interior and Factors Controlling the Biological Pump: A Synthesis of Global Sediment Trap Programs since 1983. Prog. Oceanogr. 76, 217-285. doi:10.1016/j.pocean.2007.11.003

Ignatiades, L., Psarra, S., Zervakis, V., Pagou, K., Souvermezoglou, E., Assimakopoulou, G., et al. (2002). Phytoplankton Size-Based Dynamics in the Aegean Sea (Eastern Mediterranean). J. Mar. Syst. 36, 11-28. doi:10.1016/ s0924-7963(02)00132-x

Jeandel, C., Rutgers Van Der Loeff, M., Lam, P. J., Roy-Barman, M., Sherrell, R. M., Kretschmer, S., et al. (2015). What Did We Learn about Ocean Particle Dynamics in the GEOSECS-JGOFS Era?. Prog. Oceanogr. 133, 6-16. doi:10.1016/j.pocean.2014.12.018 
Karageorgis, A. P., and Anagnostou, C. L. (2003). Seasonal Variation in the Distribution of Suspended Particulate Matter in the Northwest Aegean Sea. J. Geophys. Res. Oceans 108, 30-31. doi:10.1029/2002jc001672

Karageorgis, A. P., Drakopoulos, P. G., Chaikalis, S., Spyridakis, N., and Psarra, S. (2017a). "Estimation of the Particle Size Distribution Slope with 3 Methods: Implications for the Optical Backscattering Ratio and the Bulk Refractive index," in Proceedings of SPIE - The International Society for Optical Engineering, 10444.

Karageorgis, A. P., Drakopoulos, P. G., Psarra, S., Pagou, K., Krasakopoulou, E., Banks, A. C., et al. (2017b). Particle Characterization and Composition in the NE Aegean Sea: Combining Optical Methods and Biogeochemical Parameters. Cont. Shelf Res. 149, 96-111. doi:10.1016/j.csr.2017.03.008

Karageorgis, A. P., Gardner, W. D., Georgopoulos, D., Mishonov, A. V., Krasakopoulou, E., and Anagnostou, C. (2008). Particle Dynamics in the Eastern Mediterranean Sea: A Synthesis Based on Light Transmission, PMC, and POC Archives (1991-2001). Deep Sea Res. Part Oceanogr. Res. Pap. 55, 177-202. doi:10.1016/j.dsr.2007.11.002

Karageorgis, A. P., Gardner, W. D., Mikkelsen, O. A., Georgopoulos, D., Ogston, A. S., Assimakopoulou, G., et al. (2014). Particle Sources over the Danube River delta, Black Sea Based on Distribution, Composition and Size Using Optics, Imaging and Bulk Analyses. J. Mar. Syst. 131, 74-90. doi:10.1016/ j.jmarsys.2013.11.013

Karageorgis, A. P., Georgopoulos, D., Kanellopoulos, T. D., Mikkelsen, O. A., Pagou, K., Kontoyiannis, H., et al. (2012). Spatial and Seasonal Variability of Particulate Matter Optical and Size Properties in the Eastern Mediterranean Sea. J. Mar. Syst. 105-108, 123-134. doi:10.1016/j.jmarsys.2012.07.003

Karageorgis, A. P., Kontoyiannis, H., Stavrakakis, S., Krasakopoulou, E., Gogou, A., Kanellopoulos, Th. D., Rousakis, G., Malinverno, E., Triantaphyllou, M. V., and Lykousis, V. (2018). Particle dynamics and fluxes in canyons and open slopes of the southern Cretan margin (Eastern Mediterranean). Progress in Oceanography. 169, 33-47. doi:10.1016/j.pocean.2017.12.009

Kerhervé, P., Minagawa, M., Heussner, S., and Monaco, A. (2001). Stable Isotopes $(13 \mathrm{C} / 12 \mathrm{C}$ and $15 \mathrm{~N} / 14 \mathrm{~N})$ in Settling Organic Matter of the Northwestern Mediterranean Sea: Biogeochemical Implications. Oceanol. Acta 24, S77-S85. doi:10.1016/s0399-1784(00)01111-7

Koppelmann, R., Böttger-Schnack, R., Möbius, J., and Weikert, H. (2009). Trophic Relationships of Zooplankton in the Eastern Mediterranean Based on Stable Isotope Measurements. J. Plankton Res. 31, 669-686. doi:10.1093/plankt/ fbp013

Kostadinov, T. S., Siegel, D. A., Maritorena, S., and Guillocheau, N. (2012). Optical Assessment of Particle Size and Composition in the Santa Barbara Channel, California. Appl. Opt. 51, 3171-3189. doi:10.1364/ao.51.003171

Kovačević, V., Gačić, M., and Poulain, P.-M. (1999). Eulerian Current Measurements in the Strait of Otranto and in the Southern Adriatic. J. Mar. Syst. 20, 255-278.

Krom, M. D., Emeis, K.-C., and Van Cappellen, P. (2010). Why Is the Eastern Mediterranean Phosphorus Limited?. Prog. Oceanogr. 85, 236-244. doi:10.1016/j.pocean.2010.03.003

Krom, M., Kress, N., Berman-Frank, I., and Rahav, E. (2014). "Past, Present and Future Patterns in the Nutrient Chemistry of the Eastern Mediterranean," in The Mediterranean Sea: Its History and Present Challenges. Editors Goffredo, S., and Dubinsky, Z., 49-68. doi:10.1007/978-94-007-6704-1_4

Lagaria, A., Psarra, S., Lefèvre, D., Van Wambeke, F., Courties, C., Pujo-Pay, M., et al. (2011). The Effects of Nutrient Additions on Particulate and Dissolved Primary Production and Metabolic State in Surface Waters of Three Mediterranean Eddies. Biogeosciences 8, 2595-2607. doi:10.5194/bg-8-25952011

Leroux, R., Gregori, G., Leblanc, K., Carlotti, F., Thyssen, M., Dugenne, M., et al. (2018). Combining Laser Diffraction, Flow Cytometry and Optical Microscopy to Characterize a Nanophytoplankton Bloom in the Northwestern Mediterranean. Prog. Oceanogr. 163, 248-259. doi:10.1016/ j.pocean.2017.10.010

Li, P., and Tanhua, T. (2020). Recent Changes in Deep Ventilation of the Mediterranean Sea; Evidence From Long-Term Transient Tracer Observations. Front. Mar. Sci. 7, 594. doi:10.3389/fmars.2020.00594

Loisel, H, and Morel, A. (1998). Light scattering and chlorophyll concentration in Case 1 waters: A reexamination. Limnology and Oceanography. doi:10.4319/ lo.1998.43.5.0847
Loisel, H., Vantrepotte, V., Norkvist, K., Mériaux, X., Kheireddine, M., Ras, J., et al. (2011). Characterization of the Bio-Optical Anomaly and Diurnal Variability of Particulate Matter, as Seen from Scattering and Backscattering Coefficients, in Ultra-Oligotrophic Eddies of the Mediterranean Sea. Biogeosciences 8, 3295-3317. doi:10.5194/bg-8-3295-2011

López-Sandoval, D. C., Fernández, A., and Marañón, E. (2011). Dissolved and Particulate Primary Production along a Longitudinal Gradient in the Mediterranean Sea. Biogeosciences 8, 815-825. doi:10.5194/bg-8-815-2011

Ludwig, W., Dumont, E., Meybeck, M., and Heussner, S. (2009). River Discharges of Water and Nutrients to the Mediterranean and Black Sea: Major Drivers for Ecosystem Changes during Past and Future Decades?. Prog. Oceanogr. 80, 199-217. doi:10.1016/j.pocean.2009.02.001

Malanotte-Rizzoli, P. (2001). "Current Systems in the Mediterranean Sea," in Encyclopedia of Ocean Sciences. 2nd Edn. 744-751. doi:10.1016/b978012374473-9.00375-1

Many, G., Bourrin, F., Durrieu De Madron, X., Pairaud, I., Gangloff, A., Doxaran, D., et al. (2016). Particle Assemblage Characterization in the Rhone River ROFI J. Mar. Syst. 157, 39-51. doi:10.1016/j.jmarsys.2015.12.010

Mara, P., Mihalopoulos, N., Gogou, A., Daehnke, K., Schlarbaum, T., Emeis, K. C., et al. (2009). Isotopic Composition of Nitrate in Wet and Dry Atmospheric Deposition on Crete in the Eastern Mediterranean Sea. Glob. Biogeochem. Cycles 23, GB4002. doi:10.1029/2008gb003395

Mari, X., Beauvais, S., Lemée, R., and Pedrotti, M. L. (2001). Non-Redfield C:N Ratio of Transparent Exopolymeric Particles in the Northwestern Mediterranean Sea. Limnol. Oceanogr. 46, 1831-1836. doi:10.4319/ lo.2001.46.7.1831

Mariotti, A., Germon, J. C., Hubert, P., Kaiser, P., Letolle, R., Tardieux, A., et al. (1981). Experimental Determination of Nitrogen Kinetic Isotope Fractionation: Some Principles; Illustration for the Denitrification and Nitrification Processes. Plant Soil 62, 413-430. doi:10.1007/bf02374138

Markaki, Z., Loÿe-Pilot, M. D., Violaki, K., Benyahya, L., and Mihalopoulos, N. (2010). Variability of Atmospheric Deposition of Dissolved Nitrogen and Phosphorus in the Mediterranean and Possible Link to the Anomalous Seawater N/P Ratio. Mar. Chem. 120, 187-194. doi:10.1016/ j.marchem.2008.10.005

Martínez-Pérez, A. M., Álvarez-Salgado, X. A., Arístegui, J., and Nieto-Cid, M. (2017). Deep-Ocean Dissolved Organic Matter Reactivity Along the Mediterranean Sea: Does Size Matter?. Sci. Rep. 7, 5687. doi:10.1038/s41598017-05941-6

Mayot, N., D'ortenzio, F., Ribera d'Alcalà, M., Lavigne, H., and Claustre, H. (2016). Interannual Variability of the Mediterranean Trophic Regimes from Ocean Color Satellites. Biogeosciences 13, 1901-1917. doi:10.5194/bg-131901-2016

Meador, T. B., Aluwihare, L. I., and Mahaffey, C. (2007). Isotopic Heterogeneity and Cycling of Organic Nitrogen in the Oligotrophic Ocean. Limnol. Oceanogr. 52, 934-947. doi:10.4319/lo.2007.52.3.0934

Meador, T. B., Gogou, A., Spyres, G., Herndl, G. J., Krasakopoulou, E., Psarra, S., et al. (2010). Biogeochemical Relationships between Ultrafiltered Dissolved Organic Matter and Picoplankton Activity in the Eastern Mediterranean Sea. Deep Sea Res. Part Topical Stud. Oceanogr. 57, 1460-1477. doi:10.1016/ j.dsr2.2010.02.015

Mikkelsen, O. A., Hill, P. S., and Milligan, T. G. (2006). Single-Grain, Microfloc and Macrofloc Volume Variations Observed with a LISST-100 and a Digital Floc Camera. J. Sea Res. 55, 87-102. doi:10.1016/j.seares.2005.09.003

Millot, C. (1999). Circulation in the Western Mediterranean Sea. J. Mar. Syst. 20, 423-442. doi:10.1016/s0924-7963(98)00078-5

Millot, C., and Taupier-Letage, I. (2005). Additional Evidence of LIW Entrainment across the Algerian Subbasin by Mesoscale Eddies and Not by a Permanent Westward Flow. Prog. Oceanogr. 66, 231-250. doi:10.1016/ j.pocean.2004.03.002

Möbius, J. (2013). Isotope Fractionation during Nitrogen Remineralization (Ammonification): Implications for Nitrogen Isotope Biogeochemistry. Geochim. Cosmochim. Acta 105, 422-432. doi:10.1016/j.gca.2012.11.048

Möbius, J., Lahajnar, N., and Emeis, K.-C. (2010). Diagenetic Control of Nitrogen Isotope Ratios in Holocene Sapropels and Recent Sediments from the Eastern Mediterranean Sea. Biogeosciences 7, 3901-3914. doi:10.5194/bg-7-3901-2010

Moisander, P. H., Benavides, M., Bonnet, S., Berman-Frank, I., White, A. E., and Riemann, L. (2017). Chasing after Non-cyanobacterial Nitrogen Fixation in 
marine Pelagic Environments. Front. Microbiol. 8, 1736. doi:10.3389/ fmicb.2017.01736

Moon, J. Y., Lee, K., Tanhua, T., Kress, N., and Kim, I. N. (2016). Temporal Nutrient Dynamics in the Mediterranean Sea in Response to Anthropogenic Inputs. Geophys. Res. Lett. 43, 5243-5251. doi:10.1002/2016gl068788

Moutin, T., Van Wambeke, F., and Prieur, L. (2012). Introduction to the Biogeochemistry from the Oligotrophic to the Ultraoligotrophic Mediterranean (BOUM) experiment. Biogeosciences 9, 3817-3825. doi:10.5194/bg-9-3817-2012

Ortega-Retuerta, E., Mazuecos, I. P., Reche, I., Gasol, J. M., Álvarez-Salgado, X. A., Álvarez, M., et al. (2019). Transparent Exopolymer Particle (TEP) Distribution and In Situ Prokaryotic Generation across the Deep Mediterranean Sea and Nearby North East Atlantic Ocean. Prog. Oceanogr. 173, 180-191. doi:10.1016/ j.pocean.2019.03.002

Ortega-Retuerta, E., Sala, M. M., Borrull, E., Mestre, M., Aparicio, F. L., Gallisai, R., et al. (2017). Horizontal and Vertical Distributions of Transparent Exopolymer Particles (TEP) in the NW Mediterranean Sea Are Linked to Chlorophyll a and O2 Variability. Front. Microbiol. 7, 2159. doi:10.3389/fmicb.2016.02159

Pantoja, S., Repeta, D. J., Sachs, J. P., and Sigman, D. M. (2002). Stable Isotope Constraints on the Nitrogen Cycle of the Mediterranean Sea Water Column. Deep Sea Res. Part Oceanogr. Res. Pap. 49, 1609-1621. doi:10.1016/s09670637(02)00066-3

Parinos, C., Gogou, A., Krasakopoulou, E., Lagaria, A., Giannakourou, A., Karageorgis, A. P., et al. (2017). Transparent Exopolymer Particles (TEP) in the NE Aegean Sea Frontal Area: Seasonal Dynamics under the Influence of Black Sea Water. Cont. Shelf Res. 149, 112-123. doi:10.1016/j.csr.2017.03.012

Passow, U. (2002). Production of Transparent Exopolymer Particles (TEP) by Phyto- and Bacterioplankton. Mar. Ecol. Prog. Ser. 236, 1-12. doi:10.3354/ meps 236001

Pavlidou, A., Velaoras, D., Karageorgis, A. P., Rousselaki, E., Parinos, C., Dähnke, K., et al. (2020). Seasonal Variations of Biochemical and Optical Properties, Physical Dynamics and N Stable Isotopic Composition in Three Northeastern Mediterranean Basins (Aegean, Cretan and Ionian Seas). Deep Sea Res. Part Topical Stud. Oceanogr. 171, 104704. doi:10.1016/j.dsr2.2019.104704

Pedrosa-Pamies, R., Parinos, C., Sanchez-Vidal, A., Calafat, A., Canals, M., Velaoras, D., et al. (2021). Atmospheric and Oceanographic Forcing Impact Particle Flux Composition and Carbon Sequestration in the Eastern Mediterranean Sea: A Three-Year Time-Series Study in the Deep Ierapetra Basin. Front. Earth Sci. 9, 591948. doi:10.3389/feart.2021.591948

Pedrosa-Pàmies, R., Sanchez-Vidal, A., Canals, M., Lampadariou, N., Velaoras, D., Gogou, A., et al. (2016). Enhanced Carbon export to the Abyssal Depths Driven by Atmosphere Dynamics. Geophys. Res. Lett. 43, 8626-8636. doi:10.1002/ $2016 \mathrm{gl069781}$

Peterson, B. J., and Fry, B. (1987). Stable Isotopes in Ecosystem Studies. Annu. Rev. Ecol. Syst. 18, 293-320. doi:10.1146/annurev.es.18.110187.001453

Qiu, Z., Sun, D., Hu, C., Wang, S., Zheng, L., Huan, Y., et al. (2016). Variability of Particle Size Distributions in the Bohai Sea and the Yellow Sea. Remote Sens. 8, 949. doi:10.3390/rs8110949

Rahav, E., Bar-Zeev, E., Ohayon, S., Elifantz, H., Belkin, N., Herut, B., et al. (2013). Dinitrogen Fixation in Aphotic Oxygenated marine Environments. Front. Microbiol. 4, 227. doi:10.3389/fmicb.2013.00227

Rahav, E., Silverman, J., Raveh, O., Hazan, O., Rubin-Blum, M., Zeri, C., et al. (2019). The Deep Water of Eastern Mediterranean Sea is a Hotspot for Bacterial Activity. Deep Sea Res. Part Topical Stud. Oceanogr. 164, 135-143. doi:10.1016/ j.dsr2.2019.03.004

Roether, W., Klein, B., Manca, B. B., Theocharis, A., and Kioroglou, S. (2007). Transient Eastern Mediterranean Deep Waters in Response to the Massive Dense-Water Output of the Aegean Sea in the 1990s. Prog. Oceanogr. 74, 540-571. doi:10.1016/j.pocean.2007.03.001

Runyan, H., Reynolds, R. A., and Stramski, D. (2020). Evaluation of Particle Size Distribution Metrics to Estimate the Relative Contributions of Different Size Fractions Based on Measurements in Arctic Waters. J. Geophys. Res. Oceans 125, e2020JC016218. doi:10.1029/2020jc016218

Santinelli, C., Nannicini, L., and Seritti, A. (2010). DOC Dynamics in the Meso and Bathypelagic Layers of the Mediterranean Sea. Deep Sea Res. Part Topical Stud. Oceanogr. 57, 1446-1459. doi:10.1016/j.dsr2.2010.02.014

Schlitzer, R. (2018). Ocean Data View. Available at: http://odv.awi.de.
Schroeder, K., Chiggiato, J., Bryden, H. L., Borghini, M., and Ben Ismail, S. (2016) Abrupt Climate Shift in the Western Mediterranean Sea. Sci. Rep. 6, 23009. doi:10.1038/srep23009

Schroeder, K., Chiggiato, J., Josey, S. A., Borghini, M., Aracri, S., and Sparnocchia, S. (2017). Rapid Response to Climate Change in a Marginal Sea. Sci. Rep. 7, 4065. doi:10.1038/s41598-017-04455-5

Siokou-Frangou, I., Bianchi, M., Christaki, U., Christou, E. D., Giannakourou, A., Gotsis, O., et al. (2002). Carbon Flow in the Planktonic Food Web along a Gradient of Oligotrophy in the Aegean Sea (Mediterranean Sea). J. Mar. Syst. 33-34, 335-353. doi:10.1016/s0924-7963(02)00065-9

Sisma-Ventura, G., Yam, R., Kress, N., and Shemesh, A. (2016). Water Column Distribution of Stable Isotopes and Carbonate Properties in the South-Eastern Levantine basin (Eastern Mediterranean): Vertical and Temporal Change. J. Mar. Syst. 158, 13-25. doi:10.1016/j.jmarsys.2016.01.012

Stavrakakis, S., Gogou, A., Krasakopoulou, E., Karageorgis, A. P., Kontoyiannis, H., Rousakis, G., Velaoras, D., Perivoliotis, L., Kambouri, G., Stavrakaki, I., and Lykousis, V. (2013). Downward fluxes of sinking particulate matter in the deep Ionian Sea (NESTOR site), Eastern Mediterranean: Seasonal and interannual variability. Biogeosciences 10, 7235-7254. doi:10.5194/bg-10-7235-2013

Stöven, T., and Tanhua, T. (2014). Ventilation of the Mediterranean Sea Constrained by Multiple Transient Tracer Measurements. Ocean Sci. 10, 439-457. doi:10.5194/os-10-439-2014

Struck, U., Emeis, K.-C., Voß, M., Krom, M. D., and Rau, G. H. (2001). Biological Productivity during Sapropel S5 Formation in the Eastern Mediterranean Sea: Evidence from Stable Isotopes of Nitrogen and Carbon. Geochim. Cosmochim. Acta 65, 3249-3266. doi:10.1016/s0016-7037(01)00668-8

Stumm, W., and Morgan, J. J. (1981). Aquatic Chemistry: An Introduction Emphasizing Chemical Equilibria in Natural Waters. 2nd Edn. New York: John Wiley \& Sons.

Tanaka, T., Zohary, T., Krom, M. D., Law, C. S., Pitta, P., Psarra, S., et al. (2007). Microbial Community Structure and Function in the Levantine Basin of the Eastern Mediterranean. Deep Sea Res. Part Oceanogr. Res. Pap. 54, 1721-1743. doi:10.1016/j.dsr.2007.06.008

Tanhua, T., Hainbucher, D., Schroeder, K., Cardin, V., Álvarez, M., and Civitarese, G. (2013). The Mediterranean Sea System: A Review and an Introduction to the Special Issue. Ocean Sci. 9, 789-803. doi:10.5194/os-9-789-2013

Teira, E., José Pazó, M., Serret, P., and Fernández, E. (2001). Dissolved Organic Carbon Production by Microbial Populations in the Atlantic Ocean. Limnol. Oceanogr. 46, 1370-1377. doi:10.4319/lo.2001.46.6.1370

Testor, P., Bosse, A., Houpert, L., Margirier, F., Mortier, L., Legoff, H., et al. (2018). Multiscale Observations of Deep Convection in the Northwestern Mediterranean Sea During Winter 2012-2013 Using Multiple Platforms. J. Geophys. Res. Oceans 123, 1745-1776. doi:10.1002/2016jc012671

Turley, C., Bianchi, M., Christaki, U., Conan, P., Harris, J., Psarra, S., et al. (2000). Relationship Between Primary Producers and Bacteria in an Oligotrophic SeaThe Mediterranean and Biogeochemical Implications. Mar. Ecol. Prog. Ser. 193, 11-18. doi:10.3354/meps193011

Turner, J. S., Pretty, J. L., and Mcdonnell, A. M. P. (2017). Marine Particles in the Gulf of Alaska Shelf System: Spatial Patterns and Size Distributions from In Situ Optics. Cont. Shelf Res. 145, 13-20. doi:10.1016/j.csr.2017.07.002

Twardowski, M. S., Boss, E., Macdonald, J. B., Pegau, W. S., Barnard, A. H., and Zaneveld, J. R. V. (2001). A Model for Estimating Bulk Refractive index from the Optical Backscattering Ratio and the Implications for Understanding Particle Composition in Case I and Case II Waters. J. Geophys. Res. 106, 14129-14142. doi:10.1029/2000jc000404

Velaoras, D., Papadopoulos, V. P., Kontoyiannis, H., Cardin, V., and Civitarese, G. (2019). Water Masses and Hydrography during April and June 2016 in the Cretan Sea and Cretan Passage (Eastern Mediterranean Sea). Deep Sea Res. Part Topical Stud. Oceanogr. 164, 25-40. doi:10.1016/j.dsr2.2018.09.005

Velaoras, D., Papadopoulos, V. P., Kontoyiannis, H., Papageorgiou, D. K., and Pavlidou, A. (2017). The Response of the Aegean Sea (Eastern Mediterranean) to the Extreme 2016-2017 Winter. Geophys. Res. Lett. 44, 9416-9423. doi:10.1002/2017gl074761

Volk, T., and Hoffert, M. I. (1985). "Ocean Carbon Pumps: Analysis of Relative Strengths and Efficiencies in Ocean-Driven Atmospheric $\mathrm{CO}_{2}$ Changes," in The Carbon Cycle and Atmospheric $\mathrm{CO}_{2}$ : Natural Variations Archean to present. Chapman Conference Papers, 1984. Editors Sundquist, E. T., and Broecker, W. S. (New York University, NY: American Geophysical Union), 99-110. 
Wada, E., and Hattori, A. (1991). Variation of Nitrogen in the Sea: Forms, Abundances and Rate Processes. Boca Raton, FL: CRC Press, 208.

Waser, N., Yin, K., Yu, Z., Tada, K., Harrison, P., Turpin, D., et al. (1998). Nitrogen Isotope Fractionation During Nitrate, Ammonium and Urea Uptake by marine Diatoms and Coccolithophores under Various Conditions of N Availability. Mar. Ecol. Prog. Ser. 169, 29-41. doi:10.3354/meps169029

White, A. E., Letelier, R. M., Whitmire, A. L., Barone, B., Bidigare, R. R., Church, M. J., et al. (2015). Phenology of Particle Size Distributions and Primary Productivity in the N Orth P Acific Subtropical Gyre ( S Tation ALOHA ). J. Geophys. Res. Oceans 120, 7381-7399. doi:10.1002/ $2015 \mathrm{jc} 010897$

Wu, J., Calvert, S. E., Wong, C. S., and Whitney, F. A. (1999). Carbon and Nitrogen Isotopic Composition of Sedimenting Particulate Material at Station Papa in the Subarctic Northeast Pacific. Deep Sea Res. Part Topical Stud. Oceanogr. 46, 2793-2832. doi:10.1016/s0967-0645(99)00084-3

Wüst, G. (1961). On the Vertical Circulation of the Mediterranean Sea. J. Geophys. Res. 66, 3261-3271. doi:10.1029/jz066i010p03261

Xi, H., Larouche, P., Tang, S., and Michel, C. (2014). Characterization and Variability of Particle Size Distributions in Hudson Bay, Canada. J. Geophys. Res. Oceans 119, 3392-3406. doi:10.1002/2013jc009542

Yamada, Y., Fukuda, H., Uchimiya, M., Motegi, C., Nishino, S., Kikuchi, T., et al. (2015). Localized Accumulation and a Shelf-Basin Gradient of Particles in the Chukchi Sea and Canada Basin, Western Arctic. J. Geophys. Res. Oceans 120, 4638-4653. doi:10.1002/2015jc010794

Yari, S., Kovačević, V., Cardin, V., Gačić, M., and Bryden, H. L. (2012). Direct Estimate of Water, Heat, and Salt Transport through the Strait of Otranto. J. Geophys. Res. Oceans 117, C09009. doi:10.1029/2012jc007936
Zaccone, R., Boldrin, A., Caruso, G., La Ferla, R., Maimone, G., Santinelli, C., et al. (2012). Enzymatic Activities and Prokaryotic Abundance in Relation to Organic Matter along a West-East Mediterranean Transect (TRANSMED Cruise). Microb. Ecol. 64, 54-66. doi:10.1007/s00248-012-0011-4

Conflict of Interest: The authors declare that the research was conducted in the absence of any commercial or financial relationships that could be construed as a potential conflict of interest.

The reviewer TBM declared a past co-authorship with one of the authors AG to the handling editor.

Publisher's Note: All claims expressed in this article are solely those of the authors and do not necessarily represent those of their affiliated organizations, or those of the publisher, the editors and the reviewers. Any product that may be evaluated in this article, or claim that may be made by its manufacturer, is not guaranteed or endorsed by the publisher.

Copyright (c) 2021 Chaikalis, Parinos, Möbius, Gogou, Velaoras, Hainbucher, Sofianos, Tanhua, Cardin, Proestakis, Amiridis, Androni and Karageorgis. This is an open-access article distributed under the terms of the Creative Commons Attribution License (CC BY). The use, distribution or reproduction in other forums is permitted, provided the original author(s) and the copyright owner(s) are credited and that the original publication in this journal is cited, in accordance with accepted academic practice. No use, distribution or reproduction is permitted which does not comply with these terms. 